ISBN - 978-1-64945-869-8

DOI- 10.46299/isg.2020.MONO.MED.II

\section{Medical theory}

Collective monograph 
Library of Congress Cataloging-in-Publication Data

ISBN - 978-1-64945-869-8

DOI - 10.46299/isg.2020.MONO.MED.II

Authors - Rusnak Ilona, Kulachek Veronika , Kulachek Yaroslav, Bulavenko Olga, Muntian Olga, Muntian Maksym, Yarovenko Anatolii, Shcherbinska O., Slabkii H., Andriiaka Artem, Vydyborets Stanislav, Gryshchenko Viktoria, Borisenko Nataliya, Bushueva Inna, Gubenko Inna, Borisyuk Irina, Valivodz Irina, Vyshnytska Iryna, Unhurian Liana, Bieliaieva Oksana, Pietkova Iryna.

Published by Primedia eLaunch https://primediaelaunch.com/

Text Copyright (C) 2020 by the International Science Group(isg-konf.com) and authors.

Illustrations (C) 2020 by the International Science Group and authors.

Cover design: International Science Group(isg-konf.com). (C)

Cover art: International Science Group(isg-konf.com). (C)

All rights reserved. Printed in the United States of America. No part of this publication may be reproduced, distributed, or transmitted, in any form or by any means, or stored in a data base or retrieval system, without the prior written permission of the publisher. The content and reliability of the articles are the responsibility of the authors. When using and borrowing materials reference to the publication is required.

Collection of scientific articles published is the scientific and practical publication, which contains scientific articles of students, graduate students, Candidates and Doctors of Sciences, research workers and practitioners from Europe and Ukraine. The articles contain the study, reflecting the processes and changes in the structure of modern science.

The recommended citation for this publication is:

Medical theory: collective monograph / Bulavenko Olga, Muntian Olga, Muntian Maksym, Yarovenko Anatolii, - etc. - International Science Group. Boston : Primedia eLaunch, 2020. 84 p. Available at : DOI : 10.46299/isg.2020.MONO.MED.II 
TABLE OF CONTENTS

\begin{tabular}{|c|c|c|}
\hline 1 & SECTION 1. OBSTETRICS AND GYNECOLOGY & 5 \\
\hline 1.1 & $\begin{array}{l}\text { Bulavenko Olga, Muntian Olga, Muntian Maksym, Yarovenko } \\
\text { Anatolii } \\
\text { Designing of specialized support systems for making a medical } \\
\text { decision for diagnosis and predicting the risk of implantation } \\
\text { pathology developing }\end{array}$ & 5 \\
\hline 1.2 & $\begin{array}{l}\text { Shcherbinska O., Slabkii H. } \\
\text { Features of the obstetrical and gynecological care system for adult } \\
\text { female population in Ukraine }\end{array}$ & 11 \\
\hline 2 & SECTION 2. MEDICAL BUSSINES & 20 \\
\hline 2.1 & $\begin{array}{l}\text { Andriiaka Artem, Vydyborets Stanislav } \\
\text { Pathophysiological mechanisms of the formation of metabolic } \\
\text { disorders in anemia of malignant neoplasm }\end{array}$ & 20 \\
\hline 2.2 & $\begin{array}{l}\text { Gryshchenko Viktoria } \\
\text { Pro- and antioxidant processes in the body under experimental } \\
\text { enteropathology, their correction }\end{array}$ & 38 \\
\hline 2.3 & $\begin{array}{l}\text { Rusnak Ilona, Kulachek Veronika, Kulachek Yaroslav } \\
\text { Choice of water for body health }\end{array}$ & 43 \\
\hline 3 & SECTION 3. PHARMACY & 47 \\
\hline 3.1 & $\begin{array}{l}\text { Borisenko Nataliya, Bushueva Inna, Gubenko Inna } \\
\text { The design of immunostimulants and adjuvants used for the treatment } \\
\text { and prevention of animal diseases }\end{array}$ & 47 \\
\hline 3.2 & $\begin{array}{l}\text { Borisyuk Irina, Valivodz Irina } \\
\text { Biopharmaceutical classification system as a tool for drug } \\
\text { development }\end{array}$ & 51 \\
\hline
\end{tabular}




\begin{tabular}{|l|l|l|}
\hline 3.3 & $\begin{array}{l}\text { Vyshnytska Iryna, Unhurian Liana, Bieliaieva Oksana, Pietkova Iryna } \\
\text { Comorbidities as factors influencing choice of drug in arterial } \\
\text { hypertension therapy }\end{array}$ & 68 \\
\hline REFERENCE & 76 \\
\hline
\end{tabular}




\section{SECTION 1. OBSTETRICS AND GYNECOLOGY}

\subsection{Designing of specialized support systems for making a medical decision for diagnosis and predicting the risk of implantation pathology developing}

Стрімкий розвиток комп’ютерної техніки та інформаційно-комунікаційних технологій (IКТ) спричинив кардинальне технічне i технологічне переоснащення в усіх галузях суспільної діяльності і, зокрема, в медицині. Як відзначається в Концепції інформатизації охорони здоров’я України, прийнятій в 2017 році, «в розвинутих країнах цифрова трансформація вже змінила ряд індустрій та організацій, приносячи істотну вигоду як громадській охороні здоров'я, так й індивідуальному медичному обслуговуванню та адаптуючи способи надання медичних послуг і характер управління системами охорони здоров'я на всіх рівнях» $[1, \mathrm{c.} .1]$.

Однією з найважливіших задач, визначених Концепцією, є «підвищення ефективності праці лікарів, якості медичних послуг за рахунок вдосконалення робочих процесів за допомогою IКТ, впровадження систем підтримки клінічних рішень» $[1$, с.4]. Тому удосконалення і розробка інноваційних методів і засобів медичного призначення $\epsilon$ стратегічно важливим завданням для галузі української біомедичної інженерії та розвитку інформаційних технологій при формуванні та підтримки діагностичних рішень [2, с.9].

Найбільш перспективний напрямок для вирішення завдань медичного прогнозування грунтується на інтелектуальному аналізі даних із застосуванням сучасного програмного забезпечення. 
Сучасна медична діагностика базується на доказовому підході, який заснований на використанні високоточної апаратури і нових інформаційних технологіях для отримання достовірних кількісних даних про стан організму людини. Але просте підвищення точності вимірювань фізіологічних показників не дозволяє сформувати та обгрунтувати чітку кореляцію між суб'єктивними відчуттями пацієнта та діагностичними даними. Тому тільки сучасні інтелектуальні технології підтримки прийняття рішень дозволяють підвищити достовірність результатів діагностичних досліджень за рахунок використання спеціалізованих методів обробки даних та надання клініцисту додаткової, розширеної інформації щодо патологічного процесу [2, с.10].

В даний час $є$ широкий спектр комп'ютерних діагностичних систем в різних предметних областях медицини, в яких використовуються різноманітні математичні методи підтримки прийняття рішення і сучасні інформаційні технології [2-4]. Особлива увага при розробці таких систем приділяється методам обробки біомедичних сигналів 3 метою визначення діагностичних ознак [4-5].

Сучасні ІКТ, які застосовуються в медичній сфері, відчутно впливають на ефективність діагностики та лікування та загальну якість медичного обслуговування населення. Проте на сьогодні не існує універсальних медичних інформаційних систем, які б повністю забезпечували процес діагностики, лікування та прогнозування процесу протікання хвороби чи патології [6, с.167].

Специфіка діагностики захворювань чи патологічних змін полягає в тому, що на ранніх стадіях вони відзначаються поганою симптоматичністю, тому навіть досвідченому лікарю досить складно виявити ознаки, які вказують на наявність захворювання. Для розв'язання таких задач i створюються спеціалізовані інформаційні системи - системи підтримки прийняття рішень (СППР; англ. Decision Support System). СППР є інформаційними системами третього покоління і призначені не для автоматизації функцій особи, яка приймає рішення (ОПР), але для підтримки ії дій у пошуку ефективного рішення. 
Особливо важливим і перспективним є використання СППР у сфері охорони здоров'я, зокрема для медичної діагностики. За даними звіту про тенденції в галузі охорони здоров'я від Stanford Medicine [7] майбутнє охорони здоров'я залежить від ряду важливих тенденцій, серед яких виділяють прогнозування та профілактику захворюваності.

У цьому контексті, якісний аналіз даних може потенційно поліпшити лікування пацієнтів, знайти невідомі фактори ризику захворювань або виявити супутні захворювання, зробити медичну діагностику більш точною, покращити управління витратами, тощо.

Проблема репродуктивних втрат залишається однією із самих актуальних та соціально значимих в сучасному акушерстві. Частота самовільного переривання вагітності досить висока - від 15 до 23\% усіх зареєстрованих вагітностей, при цьому близько 80\% всіх репродуктивних втрат припадає на I триместр [8].

За даними Американської асоціації репродуктивної медицини (2012), загрозливий аборт, що супроводжується болем внизу живота та кров'янистими виділеннями зі статевих шляхів, спостерігається у 16-25 \% вагітностей [9]. Стабільність частоти невиношування вагітності вказує на труднощі, що виникають при веденні цієї групи пацієнток. 3 однієї сторони, вони обумовлені багатофакторністю етіології та патогенетичних механізмів захворювання. 3 іншої - недосконалістю діагностичних методик та відсутністю адекватного моніторингу ускладнень, що виникають під час вагітності.

Звичне невиношування вагітності являе собою поліетіологічний симптомокомплекс, в основі розвитку якого часто лежать структурні зміни ендометрію, інфекційні, ендокринні, імунологічні та генетичні фактори у різних поєднаннях та співвідношеннях. Майже у 50\% жінок причину звичного невиношування вагітності вияснити не вдається. 
3 однієї сторони, такі труднощі можна пояснити поліетіологічністю цього симптомокомплексу. 3 іншої сторони, важливу роль у формуванні звичного невиношування вагітності відіграють зміни в органах та системах організму, що формуються в результаті дії первинного етіологічного фактору, а в подальшому приймають незалежну участь в патогенезі цієї патології.

Одним з механізмів розвитку звичного невиношування вагітності в I-му триместрі являється порушення процесів імплантації та плацентації. До основних змін ендометрію в цей період відносять процеси ангіогенезу, згортання крові та фібринолізу, ремоделювання екстрацелюлярного матриксу. Порушення однієї чи кількох цих ланок в кінці кінців призводить до порушення формування матково-плацентарного кровотоку, що в свою чергу веде до невідповідного забезпечення плоду киснем та поживними речовинами, клінічними проявами чого можуть бути загроза переривання вагітності, завмерла вагітність чи самовільний викидень.

На сьогоднішній день $є$ багато даних, що підтверджують роль поліморфізму генів гестаційних ускладнень, в тому числі і звичного невиношування вагітності.

В той же час поліморфізм генів інших патогенетичних факторів може не приймати безпосередньої участі в патогенезі звичного невиношування, але опосередковано впливати на схильність до формування даної патології. В зв'язку з цим питання про необхідність ДНК-діагностики та визначення необхідного об'єму досліджень точкових мутацій генів у жінок із звичним невиношуванням вагітності залишається відкритим. Особливу увагу необхідно приділити вивченню поліморфізму генів рецепторів прогестерону та васкулярно-ендотеліальному фактору росту хоріона та плаценти, що мають надважливе значення для прогресування вагітності. Важливе значення в формуванні схильності до звичного невиношування вагітності має не стільки носійство мутантних алелей задіяних генів, скільки їх комбінації. Існує велика кількість робіт, присвячених ролі носійства кількох мутантних алелей в розвитку тих чи інших ускладнень вагітності. 
Відсутність тенденції до зниження частоти невиношування вагітності та періодичне іiі зростання свідчить про недосконалість своєчасної діагностики та профілактики даного стану. Звичне невиношування вагітності являє собою поліетіологічний симптомокомплекс, в основі розвитку якого часто лежать структурні зміни ендометрію, інфекційні, ендокринні, імунологічні та генетичні фактори у різних поєднаннях та співвідношеннях. Майже у 50\% жінок причину звичного невиношування вагітності вияснити не вдається.

Авторами (Булавенко O. та Мунтян O.) досліджено зв'язки між поліморфізмом генів PgR i VEgF, станом спіральних та маткових артерій у пацієнток із звичним невиношуванням вагітності в порівнянні з пацієнтками 3 реалізованою репродуктивною функцією. Встановлено, що ранніми симптомами переривання вагітності (самовільного викидня, завмерлої вагітності) у жінок із ЗН вагітності в анамнезі $є$ біль внизу живота та в поперековій ділянці, загальна слабкість, головний біль та головокружіння, кров'янисті виділення зі статевих шляхів та зниження базальної температури. При їх своєчасному виявленні та корекції ми можемо запобігти розвитку подальших патологічних змін, що призведуть до втрати вагітності.

При проведенні молекулярно-генетичного дослідження у більшості жінок виявлено поліморфізм ендотеліального фактора росту судин $(79,55 \%)$, та у 29,46\% жінок - поліморфізм гену рецепторів прогестерону. При цьому у 9,09\% жінок було виявлено поліморфізм обох генів. Обгрунтовані можливість і доцільність визначення поліморфізму гену рецепторів прогестерону та васкулоендотеліального фактора росту судин (або обох цих генів), оскільки даний стан асоціюється 3 високою ймовірністю розвитку патології імплантації плідного яйця у жінок із звичним невиношуванням вагітності.

При проведенні ультразвукового дослідження 3 допплерівським картуванням було виявлено незначне зниження ПІ та незначне підвищення IP в маткових та спіральних артеріях у жінок основної групи. 
Також у жінок із звичним невиношуванням вагітності в анамнезі спостерігалось суттєве зниження значень СДС в спіральних артеріях в порівнянні із жінками контрольної групи.

В результаті проведених досліджень встановлено, що наявність поліморфізму гену рецепторів прогестерону, васкулоендотеліального фактору росту судин (або обох цих генів), відхилення значень пульсаційного індексу, індексу резистентності та систоло-діастолічного співвідношення в маткових та спіральних артеріях (ультразвукове дослідження, УЗД) є прогностичними маркерами розвитку патології імплантації та плацентації, що в свою чергу призводить до переривання вагітності на ранніх термінах (завмерла вагітність або самовільний викидень)

Відповідно до отриманих результатів розроблено схему прегравідарної діагностики та прогнозування патології імплантації. Удосконалений алгоритм прегравідарної діагностики дозволяє ще на етапі планування вагітності визначити жінок із можливим розвитком патології імплантації та своєчасно проводити профілактику цих ускладнень. Розроблено та запропоновано нові рекомендації для скринінгового обстеження жінок із звичним невиношуванням в анамнезі для прогнозування можливої патології імплантації плідного яйця.

3 метою створення СППР для лікаря акушера-гінеколога були виконані наступні дослідження:

- вивчені клінічні особливості перебігу вагітності при патології імплантації у жінок із звичним невиношуванням;

- оцінено гени системи гемостазу, ангіогенезу та регуляції функції ендотелію у пацієнток із звичним невиношуванням вагітності: PgR i VEgF;

- вивчено та оцінено стан кровотоку в спіральних та маткових артеріях у пацієнток із звичним невиношуванням вагітності в порівнянні з пацієнтками 3 реалізованою репродуктивною функцією;

• визначено прогностичні маркери розвитку невиношування вагітності; 
- розроблено алгоритм прегравідарної діагностики та прогнозування розвитку невиношування вагітності.

Розроблена авторами СППР для лікаря акушера-гінеколога включає базу даних пацієнтів та модуль для вироблення та підтримки прийняття лікарського рішення щодо ризику невиношування вагітності на ранніх стадіях. Технологія опрацювання даних в СППР базується на методах інтелектуального аналізу даних з використанням апарату Data Mining та багатомірного статистичного аналізу. Математико-статистичний аналіз результатів УЗД кровотоку в спіральних та маткових артеріях в трьох вікових підгрупах основної та контрольної груп дозволив встановити показники-індикатори (предиктори) потенційних патологічних порушень (невиношування вагітності) та обчислити межі довірчих інтервалів для їх значень.

База даних пацієнтів містить їх особисті дані, антропометричні та клінікоанамнестичні дані, результати оглядів та обстежень, результати молекулярногенетичних досліджень та УЗД. В модулі для вироблення та підтримки прийняття лікарського рішення здійснюється поетапний аналіз прогностичних маркерів - скарг та симптомів, наявності поліморфізму гену рецепторів прогестерону та васкулоендотеліального фактору росту судин (або обох цих генів), відхилення значень пульсаційного індексу, індексу резистентності та систоло-діастолічного співвідношення в маткових та спіральних артеріях.

Розроблена СППР для лікаря акушера-гінеколога дозволяє мінімізувати ризики лікарських помилок, підвищити достовірність діагностики та обгрунтованість лікарських рішень. Інтеграція СППР в різних галузях медицини на базі інтелектуального аналізу даних та сучасного програмного забезпечення дозволить створити комплексні системи медичної діагностики та прогнозування.

\subsection{Features of the obstetrical and gynecological care system for adult female population in Ukraine}




\section{INTRODUCTION}

Taking into account the prognosis of the further decline of the people of Ukraine, the most important problem of demographic policy is the population increase. The basis positions of the demographic policy are the birth rate, care taking of the reproductive health of the population and an increase of reproductive potential [10].

The specificity of a woman's reproductive health is determined, first of all, by the peculiarities of the realization of her reproductive function. Factors that reduce the level of women's reproductive function consist mainly of a significant part of gynecological morbidity, the prevalence of sexually transmitted diseases, the deterioration of the health status of pregnant women and women in labor, and a high level of abortions and complications after them [11].

According to the statistic data, inflammatory diseases of the female genital organs are on the first place among all gynecological diseases. The prevalence and incidence of salpingitis and oophoritis in women had a tendency to decrease - in 2017 their rate among women of reproductive age were 15.82 and 8.61 per 1000 persons of the corresponding age versus 19.67 and 11.42 in 2000 respectively. During this period, in women of reproductive age, the prevalence and incidence of inflammatory diseases of the cervix increased slightly from 12.25 and 8.53 per 1000 persons of the corresponding age in 2013 up to 12.5 and 8.6 in 2017, respectively [12].

The menstrual cycle is an important indicator of the state of a woman's reproductive system. The rate of the disorders of the menstrual cycle in the structure of the gynecological diseases is $20 \%$ [13].

Non-inflammatory diseases of the female genital organs, such as cervical erosion and ectropion, also have a negative effect on the female reproductive function. There is a high level of both prevalence and morbidity of cervical erosion and ectropion in women of reproductive age, but there is a tendency to reduce these indicators from 20.05 and 10.35 per 1000 female persons of the corresponding age in 2013 to 17.5 and 8.7 in 2017 , respectively [14]. 
In recent years, the morbidity of women with malignant diseases of the organs of the female reproductive system, which cause premature mortality of women in reproductive age, has been growing [15].

Disorders of female reproductive function are also caused by sexually transmitted infections. The frequency of sexually transmitted infections in women in Ukraine is much higher than in developed European countries. However, according to the Center for Medical Statistics data, the prevalence of gonococcus infection and syphilis has been reduced significantly recently. Thus, generally, the morbidity of female population with sexually transmitted infections in 2017 was 5.6 for syphilis and 7.3 for gonococcus infection per 1000 women. The declining trend of the rate of syphilis and gonorrhea in women is of some concern due to the possibility of unsatisfactory detection of these diseases and their incomplete registration. The dynamics of women's rate of chlamydya infection, trichomoniasis and urogenital mycoplasmosis has also a downward trend and amounted to, respectively, 48.8, 160.0 and 77.1 per 1000 women in 2017 [16].

Commonly, the prevalence of abortions demonstrates both the tendencies of the women's reproductive behavior and their reproductive health status. The reduction in the total abortion rate per 1000 women of reproductive age compared to previous years (32.09 in 2000, 13.94 in 2010, 12.24 in 2013 and 8.78 in 2017) is important, but it should mentioned that in developed countries this indicator is in 2-3 times lower. In Ukraine, in 2000, every second pregnancy ended with abortion (51.43 per 100 pregnancies), in 2017 - every fifth pregnancy (25.73 per 100 pregnancies) [17]. At the same time, the rate of women whose pregnancy is terminated by abortion in Eastern European countries is up to $14 \%$, in Western European countries - up to 3 $\%$, in Latin America - $9 \%$, in Africa - $11 \%$ [18].

It should be noted that in matters of reproductive health and the strengthening of reproductive potential, the main position in the country is based on the strategies that can help reduce reproductive losses. It is possible to provide a favorable outcome of each desired pregnancy in the conditions of reducing the number of women in reproductive age, which is the main task of modern obstetrical care, in the case of fact 
of the international standard of reproductive health and effective obstetrical and gynecological care for women.

1. The resource of the obstetric and gynecological care system for the adult female population in Ukraine

At the beginning of the research, we studied and analyzed the network of healthcare institutions in Ukraine in the context of administrative territories in which obstetrical and gynecological care to the adult female population is provided. The results are demonstrated in table 1.1.

Table 1.1

The network of healthcare institutions of obstetric and gynecological care in Ukraine in different administrative territories, 2019

\begin{tabular}{|c|c|c|c|c|c|c|c|}
\hline \multirow[b]{2}{*}{$\begin{array}{l}\text { Administrative } \\
\text { region }\end{array}$} & \multicolumn{2}{|c|}{$\begin{array}{l}\text { Maternity hospitals } \\
\text { and perinatal centers }\end{array}$} & \multicolumn{5}{|c|}{ Departments / offices in outpatient clinics } \\
\hline & TOTAL & $\begin{array}{c}\text { female } \\
\text { dispensaries } \\
\text { in these } \\
\text { institutions }\end{array}$ & $\begin{array}{c}\text { female } \\
\text { dispensaries }\end{array}$ & $\begin{array}{l}\text { obstetrical } \\
\text { and } \\
\text { gynecolo- } \\
\text { gical }\end{array}$ & $\begin{array}{l}\text { examina- } \\
\text { tion } \\
\text { rooms }\end{array}$ & $\begin{array}{c}\text { family } \\
\text { planning and } \\
\text { human } \\
\text { reproduction }\end{array}$ & $\begin{array}{l}\text { medical } \\
\text { and } \\
\text { genetic }\end{array}$ \\
\hline Ukraine & 71 & 68 & 331 & 841 & 876 & 81 & 63 \\
\hline Vinnitsa & 2 & 2 & 14 & 38 & 42 & 1 & 2 \\
\hline Volyn & 3 & 3 & 6 & 27 & 25 & 3 & 1 \\
\hline Dnipropetrovsk & 6 & 5 & 5 & 110 & 47 & 4 & 7 \\
\hline Donetsk & 3 & 3 & 20 & 33 & 26 & 2 & 2 \\
\hline Zhytomyr & 1 & 1 & 10 & 30 & 33 & - & 1 \\
\hline Transcarpathia & 1 & 1 & 12 & 24 & 24 & 3 & 2 \\
\hline Zaporizhzhia & 5 & 5 & 24 & 27 & 23 & 2 & 2 \\
\hline Ivano-Frankivsk & 3 & 2 & 6 & 34 & 23 & 1 & 3 \\
\hline Kyiv & 2 & 2 & 26 & 30 & 36 & 16 & 2 \\
\hline Kirovohrad & 1 & 1 & 2 & 32 & 38 & 17 & 4 \\
\hline Lugansk & - & - & 10 & 19 & 14 & - & 1 \\
\hline Lviv & 4 & 2 & 16 & 66 & 118 & 1 & - \\
\hline Mykolaiv & 3 & 3 & 8 & 34 & 36 & 1 & 1 \\
\hline Odessa & 5 & 10 & 40 & 21 & 44 & 2 & 3 \\
\hline Poltava & 2 & 2 & 25 & 19 & 33 & 6 & 4 \\
\hline Rivne & 3 & 3 & 8 & 27 & 39 & 5 & 1 \\
\hline Sumy & 2 & 2 & 7 & 21 & 47 & 1 & 5 \\
\hline Ternopil & 1 & 1 & 2 & 34 & 10 & 1 & 2 \\
\hline Kharkiv & 7 & 3 & 46 & 41 & 41 & 6 & 5 \\
\hline Kherson & 1 & 1 & 6 & 30 & 25 & 2 & 2 \\
\hline Khmelnitsk & 2 & 2 & 10 & 30 & 42 & 2 & 4 \\
\hline Cherkasy & 2 & 2 & 2 & 33 & 43 & 1 & 2 \\
\hline Chernivtsi & 2 & 2 & 2 & 20 & 17 & 1 & 2 \\
\hline
\end{tabular}




\begin{tabular}{|l|r|r|r|r|r|r|r|}
\hline Chernihiv & 2 & 3 & 9 & 32 & 36 & - & 3 \\
\hline City of Kyiv & 8 & 7 & 15 & 29 & 14 & 3 & 2 \\
\hline
\end{tabular}

There is a large network of health care institutions in Ukraine, which provides obstetrical and gynecological care to the adult female population. Such institutions include maternity hospitals and perinatal centers with female dispensaries and departments/offices in outpatient clinics: female dispensaries, obstetrical and gynecological offices, examination rooms, departments/offices of family planning and human reproduction, medical genetic offices. The analysis demonstrated that these health care institutions function in all administrative regions except the Zhytomyr, Lugansk and Chernihiv regions, where the departments/offices for family planning and human reproduction are absent, in the Lviv region there are no medical genetic offices, and also, there is no perinatal center in the Lugansk region. In addition to these healthcare institutions, there are a big number of the obstetrical and gynecological beds in the multiprofile hospitals with specialized and highly specialized medical care for adults. In fig. 1.1 the data of the number of obstetrical and gynecological beds in multiprofile hospitals with specialized and highly specialized medical care are presented. In the health care system in Ukraine, there are 9575 hospital beds for pregnant women and women in labor, 3645 of them are located in the maternity hospitals and perinatal centers, 431 - in the regional hospitals, 1448 - in the city hospitals, 3949 - in the central district and district hospitals; there are 6416 hospital beds for women with pathological pregnancy including 3050 beds in the maternity hospitals and perinatal centers, 478 - in the regional hospitals, 820 - in the city hospitals and 2018 - in the central district and district hospitals; there are 12210 hospital gynecological beds for adult women, including 2932 beds in the maternity hospitals and perinatal centers, 635 - in the regional hospitals, 2838 - in the city hospitals and 5275 - in the central district and district hospitals. Besides this, there are 87 hospital beds for women who are going to interrupt pregnancy, including 59 beds in the maternity hospitals and perinatal 
centers, 18 hospital beds are located in the central district and district hospitals and 10 beds - in the city hospitals.

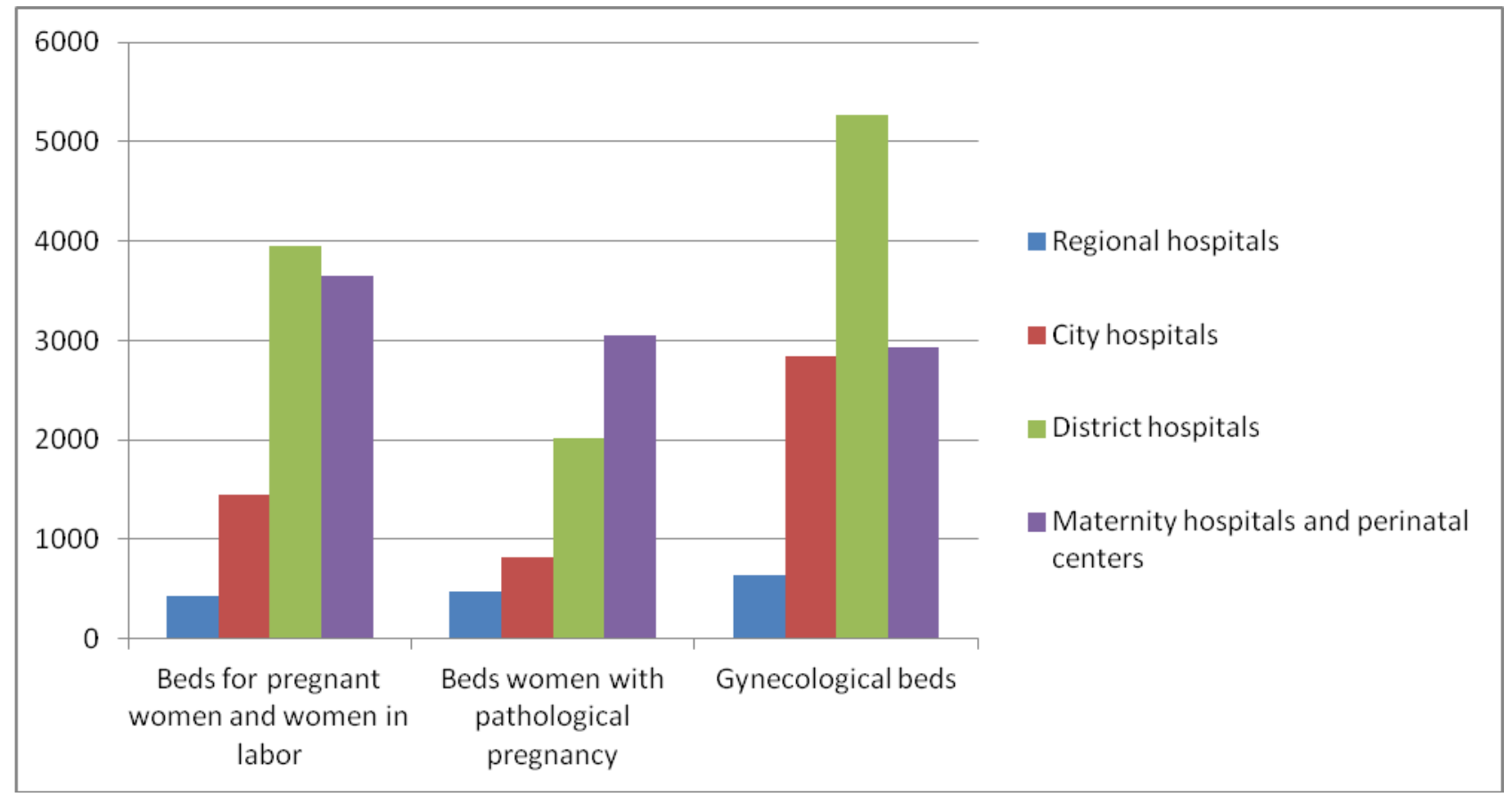

Fig.1.1 The number and distribution of obstetrical and gynecological beds by type of healthcare institution and the profile of their use, 2019

In addition to inpatient hospital beds there are 982 outpatient hospital beds in 53 female dispensaries. The largest number of obstetrical and gynecological outpatient beds is in the Dnipropetrovsk region (90 beds), while in the Zhytomyr and Lugansk regions this type of beds is absent.

Obstetricians and gynecologists are the specialists who provide obstetrical and gynecological care to the female population. Data on the staff positions of obstetrician-gynecologists in the administrative regions of the country and the level of their staffing are presented in table 1.2.

Table 1.2

Staff positions of obstetrician-gynecologists and their level of staffing in administrative regions in Ukraine, 2019

\begin{tabular}{|l|c|c|r|r|r|r|r|}
\hline \multirow{2}{*}{ Administrative region } & \multirow{2}{*}{$\begin{array}{c}\text { Staff } \\
\text { positions }\end{array}$} & \multirow{2}{*}{$\begin{array}{l}\text { Occupied } \\
\text { positions }\end{array}$} & \multirow{2}{*}{$\begin{array}{c}\text { Basic } \\
\text { workers }\end{array}$} & \multicolumn{2}{|c|}{ Staffing, } & \multicolumn{2}{|c|}{$\begin{array}{c}\text { The difference between } \\
\text { full-time positions and }\end{array}$} \\
\cline { 5 - 8 } & & & $\begin{array}{c}\text { occupied } \\
\text { positions }\end{array}$ & basic workers & $\begin{array}{c}\text { occupied } \\
\text { positions }\end{array}$ & $\begin{array}{c}\text { basic } \\
\text { workers }\end{array}$ \\
\hline Ukraine & 9853.25 & 9090.25 & 8631 & 92.26 & 87.60 & 763.00 & 1222.25 \\
\hline
\end{tabular}




\begin{tabular}{|l|r|r|r|r|r|r|r|}
\hline Vinnitsa & 398.00 & 370.25 & 345 & 93.03 & 86.68 & 27.75 & 53.00 \\
\hline Volyn & 286.75 & 263.00 & 244 & 91.72 & 85.09 & 23.75 & 42.75 \\
\hline Dnipropetrovsk & 818.25 & 741.50 & 666 & 90.62 & 81.39 & 76.75 & 152.25 \\
\hline Donetsk & 432.25 & 355.50 & 282 & 82.24 & 65.24 & 76.75 & 150.25 \\
\hline Zhytomyr & 286.50 & 272.50 & 247 & 95.11 & 86.21 & 14.00 & 39.50 \\
\hline Transcarpathia & 216.00 & 208.75 & 243 & 96.64 & 112.50 & 7.25 & -27.00 \\
\hline Zaporizhzhia & 483.50 & 440.50 & 381 & 91.11 & 78.80 & 43.00 & 102.50 \\
\hline Ivano-Frankivsk & 379.00 & 360.75 & 386 & 95.18 & 101.85 & 18.25 & -7.00 \\
\hline Kyiv & 455.25 & 400.00 & 357 & 87.86 & 78.42 & 55.25 & 98.25 \\
\hline Kirovohrad & 271.25 & 236.50 & 203 & 87.19 & 74.84 & 34.75 & 68.25 \\
\hline Lugansk & 176.00 & 137.25 & 114 & 77.98 & 64.77 & 38.75 & 62.00 \\
\hline Lviv & 672.00 & 664.75 & 728 & 98.92 & 108.33 & 7.25 & -56.00 \\
\hline Mykolaiv & 278.25 & 250.25 & 201 & 89.94 & 72.24 & 28.00 & 77.25 \\
\hline Odessa & 591.00 & 542.25 & 569 & 91.75 & 96.28 & 48.75 & 22.00 \\
\hline Poltava & 349.50 & 311.75 & 284 & 89.20 & 81.26 & 37.75 & 65.50 \\
\hline Rivne & 335.00 & 315.00 & 291 & 94.03 & 86.87 & 20.00 & 44.00 \\
\hline Sumy & 284.50 & 252.25 & 231 & 88.66 & 81.20 & 32.25 & 53.50 \\
\hline Ternopil & 246.50 & 232.25 & 239 & 94.22 & 96.96 & 14.25 & 7.50 \\
\hline Kharkiv & 695.25 & 651.50 & 637 & 93.71 & 91.62 & 43.75 & 58.25 \\
\hline Kherson & 274.00 & 243.75 & 206 & 88.96 & 75.18 & 30.25 & 68.00 \\
\hline Khmelnitsk & 313.00 & 307.25 & 304 & 98.16 & 97.12 & 5.75 & 9.00 \\
\hline Cherkasy & 300.25 & 280.25 & 245 & 93.34 & 81.60 & 20.00 & 55.25 \\
\hline Chernivtsi & 229.00 & 221.25 & 226 & 96.62 & 98.69 & 7.75 & 3.00 \\
\hline Chernihiv & 213.00 & 203.00 & 182 & 95.31 & 85.45 & 10.00 & 31.00 \\
\hline City of Kyiv & 869.25 & 828.25 & 820 & 95.28 & 94.33 & 41.00 & 49.25 \\
\hline & & & & & & & \\
\hline
\end{tabular}

In the health care system of Ukraine there are total 9853.25 staff positions of obstetricians and gynecologists in different quantity in different administrative regions. It depends on the network of health care institutions in the regions that provide obstetrical and gynecological care and the number of the beds. The level of staffing in the health care system as a whole is $92.26 \%$ of the occupied positions and $87.60 \%$ of the basic workers (employees), but there is a difference in administrative regions. The level of employment of obstetrician-gynecologists is 4.29 per 10 thousand women with ranges from 3.06 in Donetsk region and to 6.44 in Chernivtsi region. The difference is 2.1 times. At the same time it should be mentioned that 4778.50 medical positions with the level of their staffing of $91.59 \%$ were introduced to provide outpatient obstetrical and gynecological care. There are insufficient of 1222 doctors obstetrician-gynecologists in the country to staff all positions in this specialty. 
In addition to obstetrician-gynecologists, specialized medical care for the female population is provided by oncologist-gynecologists, genetic doctors and genetic laboratory assistants. In the healthcare system of Ukraine there are 250 positions of doctors oncologist-gynecologists, a level of staffing of these doctors is 0.11 per 10 thousand female population. Also there are 88 positions of genetics with a level of staffing 0.02 and 14 positions of genetic laboratory assistants.

Among the total number of doctors who provide obstetrical and gynecological care to the female population there are $85.80 \%$ of obstetrician-gynecologist doctors, $76.80 \%$ - oncologist-gynecologists, $77.27 \%$ - geneticists, $71.43 \%$ - genetic laboratory assistants.

The nursing staff and the midwives have an important role in the providing of obstetrical and gynecological care to the female population. Data on the number of midwives and their qualifications in different administrative regions of Ukraine are presented in table 1.3.

Table 1.3

The number of midwives and their qualifications in different administrative regions in Ukraine, 2019

\begin{tabular}{|c|c|c|c|c|c|c|}
\hline \multirow{2}{*}{$\begin{array}{l}\text { Administrative } \\
\text { region }\end{array}$} & \multirow{2}{*}{$\begin{array}{c}\text { Total } \\
\text { number } \\
\text { of } \\
\text { midwives }\end{array}$} & \multirow{2}{*}{$\begin{array}{l}\text { Among them } \\
\text { number of } \\
\text { persons with a } \\
\text { qualification } \\
\text { category }\end{array}$} & \multicolumn{3}{|c|}{$\begin{array}{l}\text { Including qualification } \\
\text { category }\end{array}$} & \multirow{2}{*}{$\begin{array}{c}\% \text { of certified } \\
\text { persons }\end{array}$} \\
\hline & & & higher & I & II & \\
\hline Ukraine & 14154 & 9685 & 6837 & 1659 & 1189 & 68.43 \\
\hline Vinnitsa & 566 & 396 & 321 & 32 & 43 & 69.96 \\
\hline Volyn & 693 & 416 & 267 & 74 & 75 & 60.03 \\
\hline Dnipropetrovsk & 910 & 556 & 406 & 84 & 66 & 61.10 \\
\hline Donetsk & 470 & 387 & 304 & 55 & 28 & 82.34 \\
\hline Zhytomyr & 589 & 364 & 224 & 77 & 63 & 61.80 \\
\hline Transcarpathia & 409 & 293 & 237 & 32 & 24 & 71.64 \\
\hline Zaporizhzhia & 481 & 312 & 189 & 88 & 35 & 64.86 \\
\hline Ivano-Frankivsk & 692 & 460 & 317 & 84 & 59 & 66.47 \\
\hline Kyiv & 612 & 450 & 375 & 41 & 34 & 73.53 \\
\hline Kirovohrad & 358 & 292 & 204 & 51 & 37 & 81.56 \\
\hline Lugansk & 176 & 130 & 88 & 27 & 15 & 73.86 \\
\hline Lviv & 1096 & 846 & 690 & 93 & 63 & 77.19 \\
\hline Mykolaiv & 350 & 241 & 135 & 75 & 31 & 68.86 \\
\hline Odessa & 778 & 519 & 430 & 53 & 36 & 66.71 \\
\hline Poltava & 423 & 316 & 234 & 50 & 32 & 74.70 \\
\hline
\end{tabular}




\begin{tabular}{|l|r|r|r|r|r|c|}
\hline Rivne & 695 & 443 & 330 & 66 & 47 & 63.74 \\
\hline Sumy & 411 & 309 & 168 & 83 & 58 & 75.18 \\
\hline Ternopil & 617 & 380 & 249 & 69 & 62 & 61.59 \\
\hline Kharkiv & 773 & 530 & 393 & 91 & 46 & 68.56 \\
\hline Kherson & 347 & 301 & 120 & 114 & 67 & 86.74 \\
\hline Khmelnitsk & 734 & 395 & 245 & 70 & 80 & 53.81 \\
\hline Cherkasy & 495 & 340 & 268 & 42 & 30 & 68.69 \\
\hline Chernivtsi & 428 & 288 & 212 & 41 & 35 & 67.29 \\
\hline Chernihiv & 357 & 174 & 23 & 94 & 57 & 48.74 \\
\hline City of Kyiv & 694 & 547 & 408 & 73 & 66 & 78.82 \\
\hline
\end{tabular}

14154 obstetricians work in the health care system of Ukraine, $68.43 \%$ of whom have a qualification category. Among the total number of certified persons, $70.6 \%$ of doctors were certified for the highest category, $17.1 \%$ - the first one and $12.3 \%$ - the second qualification category.

\section{CONCLUSIONS}

The analysis of the resource base of the system of obstetrical and gynecological care for the adult female population in Ukraine, which includes a network of health care institutions, number of beds and human resources demonstrated that in Ukraine there is a great system of obstetrical and gynecological care generally in the country and in the administrative regions, in particular. This system can provide quality and affordable specialized medical care for adult female population of the country. 


\section{SECTION 2. MEDICAL BUSSINES}

\subsection{Pathophysiological mechanisms of the formation of metabolic disorders in anemia of malignant neoplasm}

Гіпоксія $є$ універсальним патологічним процесом, що супроводжує i визначає розвиток самої різноманітної патології. Узагальнено гіпоксію можна визначити як невідповідність потреб клітин в енергії і енергопродукції в системі мітохондріального окислювального фосфорилювання. Причини порушення продукції енергії в гіпоксичній клітині неоднозначні. Насамперед, це - розлади зовнішнього дихання, порушення кровообігу в легенях, зміни кисневотранспортної функції крові, порушення системного, регіонального кровообігу i мікроциркуляції, ендотоксемія. Безпосередньою причиною іiі виникнення в переважній більшості патологічних станів $є$ зниження доставки кисню до мітохондрій, що супроводжується пригніченням мітохондріального окислення. Порушення останнього призводить до пригнічення спорідненого 3 ним фосфорилювання i, як наслідок, викликає прогресуючий дефіцит аденозинтрифосфорної кислоти (АТФ) - універсального джерела енергії в клітині. Дефіцит енергії $є$ суттю будь-якої форми гіпоксії і обумовлює якісно однотипні метаболічні і структурні зрушення в різних органах і тканинах. Зменшення концентрації АТФ в клітинах призводить до зменшення iї інгібіторної ролі і впливу на один із ключових ферментів гліколізу фосфофруктокіназу. Активований гіпоксією гліколіз тільки частково компенсує нестачу АТФ, однак швидко викликає накопичення лактату і розвиток ацидозу із поступовим аутоінгібіруванням гліколітичних процесів [19].

Проблема вторинних змін системи крові при різних за патогенетичними механізмами розвитку захворюваннях привертає увагу не тільки науковців, а i 
фахівців різних спеціальностей. Непересічну зацікавленість викликають i порушення з боку органів і систем на фоні порушень функціонування системи крові. Гіпоксія спричинює комплексну модифікацію функцій біологічних мембран - як порушуючи структуру подвійного ліпідного прошарку мембран, так і функціонування мембранних ферментів. Порушуються або модифікуються при цьому головні функції мембран: бар'єрна, рецепторна, каталітична. Основними причинами означених порушень вважають енергодефіцит і його активацію на фоні фосфоліполізу і перекисного окислення ліпідів. Розпад фосфоліпідів і інгібірування їх синтезу призводить до підвищення концентрації ненасичених жирних кислот і посиленню їх перекисного окислення. Останнє стимулюється в результаті пригнічення активності антиоксидантних систем через розпад і пригнічення синтезу їх білкових компонентів, насамперед, супероксиддисмутази, каталази, глутатіонпероксидази, глутатіонредуктази тощо. Дефіцит енергії при гіпоксії сприяє накопиченню кальцію в цитоплазмі клітин, оскільки блокуються енергозалежні процеси вилучення кальцію із клітин, що супроводжується активацією кальцій-залежних фосфоліпази. Один iз захисних механізмів, що перешкоджає накопиченню кальцію в цитоплазмі, полягає в захопленні кальцію мітохондріями. Означене підвищується метаболічна активність мітохондрій, що спрямована на підтримку стабільності внутрішньомітохондріального заряду i перекачування протонів, що супроводжується посиленим розходом АТФ. Замикається хибне коло: нестача кисню порушує енергетичний обмін і стимулює вільнорадикальне окислення, а активація вільно радикального окислення супроводжується ушкодженням мембрани мітохондрій і лізосом, поглиблює дефіцит енергії.

За відсутності гіпоксії деякі клітини, наприклад, кардіоміоцити, отримують АТФ за рахунок розщеплення ацетил-КоА в циклі Кребса i основними джерелами енергії для них виступають глюкоза і вільні жирні кислоти. При адекватному кровопостачанні 60 - 90 \% ацетил-КоА утворюється за рахунок окислення вільних жирних кислот, а решта 10-40 \% за рахунок декарбоксилування піровиноградної кислоти (ПВК). Приблизно половина ПВК 
в клітинах утворюється за рахунок гліколізу, а інша половина - iз лактату, що потрапляє в клітини із крові. Катаболізм вільних жирних кислот порівняно із гліколізом потребує більшої кількості кисню для синтезу еквівалентної кількості АТФ. При адекватному забезпеченні киснем клітин системи гліколізу і жирнокислотна знаходяться у стані динамічної рівноваги. При виникненні гіпоксії кількість кисню, що надходить до клітини, є недостатньою для окислення жирних кислот, в результаті чого в мітохондріях відбувається накопичення недоокислених активованих форм жирних кислот ацилкарнітину, ацил-КоА, які здатні блокувати аденіннуклеотидтранслоказу, що супроводжується пригніченням транспорту синтезованого в мітохондріях АТФ в цитозоль, ушкодженням мембран клітини шляхом детергентної дії.

Компенсаторні шляхи для відновлення енергетичного статусу у клітини є наступні: підвищення ефективності використання мітохондріями дефіцитного кисню шляхом запобігання розбалансування окислення і фосфорилювання, стабілізації мембран мітохондрій; зменшенням інгібірування реакцій циклу Кребса, особливо за рахунок підтримання активності сукцинатдегідрогеназної ланки; заміною втрачених компонентів дихального ланцюга; формування нових редокс-систем, шунтуванням перевантаженого електронами дихального ланцюга; економного витрачання кисню і зниження кисневого запиту тканин або інгібіруванням шляхів його утилізації, які не є екстреними для підтримання життєдіяльності в критичних ситуаціях, наприклад, нефосфорилююче ферментативне окислення - терморегуляторне, мікросомальне тощо, неферментативне окислення ліпідів; збільшення утворення АТФ в процесі гліколізу без збільшення кількості лактату; зменшення витрачання АТФ на процеси, що не є важливими для підтримки життєдіяльності в екстрених ситуаціях, наприклад, різноманітні синтетичні відновлювальні реакції, функціонування енергозалежних транспортних систем тощо; введенням ззовні високо енергетичних сполук. Наразі одним із шляхів реалізації означених підходів є застосування фармакологічних препаратів - антигіпоксантів. 
Морфологічні зміни розвиваються в динаміці і залежать від ступеню тяжкості гіпоксії [20]. У реакції організму на гіпоксію виділяють дві стадії компенсації і декомпенсації. У стадії компенсації завдяки компенсаторнопристосувальним реакціям підтримується нормальне постачання тканин киснем. При виснаженні пристосувальних механізмів розвивається стадія декомпенсації.

Компенсаторно-пристосувальні реакції включаються шляхом рефлекторного посилення дихання, кровообігу, а також шляхом посилення транспорту кисню і змін тканинного обміну. Дихальні компенсаторні механізми: збільшення легеневої вентиляції за рахунок збудження хеморецепторів кровоносних судин через нестачу кисню і накопичення іонів водню; збільшення дихальної поверхні легень за рахунок вентиляції додаткових альвеол за поглибленого i частішого дихання [21]. Гемодинамічні компенсаторні механізми: підвищення хвилинного об'єму серця внаслідок збільшення ударного об’єму і тахікардії; підвищення тонусу кровоносних судин, пришвидшення кровообігу 3 подальшим розширенням судин; перерозподіл крові в бік переважного постачання ії життєво важливим органам і забезпечення оптимальної кровообігу в легенях, серці, головному мозку за рахунок зменшення кровопостачання шкіри, селезінки, м'язів, кишечника, які за цих обставин $є$ депо крові. Гематогенними компенсаторними механізмами вважають: еритроцитоз - збільшення вмісту еритроцитів в периферичній крові за рахунок мобілізації з депо (відносний еритроцитоз) або посилення гемопоезу (абсолютний еритроцитоз); здатність гемоглобіну зв'язувати майже нормальну кількість кисню при значному зменшенні його напруження в крові; посилення дисоціації оксигемоглобіну на кисень i гемоглобін. Тканинними компенсаторними механізмами прийнято вважати: посилення здатності тканинних ферментів утилізувати кисень 3 крові, підтримувати досить високий рівень окисних процесів і здійснювати нормальний синтез АТФ всупереч гіпоксії; більш ефективне використання енергії окисних процесів за рахунок 
посилення спряженості процесів окислення і фосфорилювання; посилення процесів безкисневого вивільнення енергії за допомогою гліколізу [21-24].

При виснаженні компенсаторно-пристосувальних механізмів розвивається киснева недостатність. Нестача кисню призводить до енергетичного голодування тканин, що лежить в основі всіх порушень при гіпоксії. Для клітин характерним є зменшення вмісту аденілових нуклеонидів - АТФ і збільшення концентрації продуктів їх розпаду - АДФ, АМФ і неорганічного фосфату. Як результат, посилюється активність гліколізу, що в свою чергу призводить до зменшення вмісту глікогену і збільшення пірувату та лактату, або ж порушення ïx співвідношення. Надлишок кислот сприяє розвитку метаболічного (не газового) ацидозу. По мірі його посилення сповільнюється інтенсивність обміну фосфопротеїнів і фосфоліпідів, знижується вміст в сироватці основних амінокислот, збільшується вміст у тканинах аміаку, виникає негативний азотистий баланс. Порушується ліпідний обмін, накопичуються продукти його обміну - кетонові тіла (ацетон, ацетооцтова і á-гідроксимасляна кислоти), рівень яких у сечі та крові зростає. Нагромаджуються продукти перекисного окислення ліпідів, що призводить до пошкодження клітинних мембран та їх органоїдів. Порушуються обмін електролітів i, перш за все, процес активного переміщення i розподілу іонів на біологічних мембранах. Збільшується кількість позаклітинного калію і внутрішньоклітинного кальцію. Паралельно 3 біохімічними, виникають і значні структурні порушення клітин. Інтенсивність обміну речовин, потужність гліколітичної системи та запаси аденілових нуклеотидів у тканинах визначають їх неоднакову чутливість до нестачі кисню. 3 огляду на це, найчутливішою до гіпоксії є нервова система.

Гіпоксія є однією з можливих причин розладів гемодинаміки, в основному, за рахунок розвитку „гіпоксичної вазодилятації”. Універсальним непрямим маркером ступеня гіпоксії периферичних тканин $є$ рівень 2,3дифосфогліцеринової кислоти (2,3-ДФГ) в еритроцитах. Гіпоксія периферичних тканин спричинює метаболічні зміни, порушення процесів синтезу та інактивації біологічно активних речовин, зокрема гістаміну, серотоніну, 
гепарину $[6,7]$. Важливу роль даних біологічно активних речовин у формуванні та розвитку чисельних патологічних синдромів відмічають також інші автори [8]. Біогенні аміни, а також гепарин, є фізіологічно активними сполуками, що відіграють суттєву роль у патохімічних, патофізіологічних механізмах формування чисельних патологічних синдромів. Дані сполуки $€$ універсальними медіаторами центральної (ЦНС) та периферичної нервової систем (ПНС).

Гістамінергічні нейрони знайдені в задньому гіпоталамусі, в межах туберомамілярних ядер. Їх нейрони мають зв'язки з кірковими та підкірковими структурами. У менших концентраціях гістамін виявлено в гіпокампі, базальних гангліях, стовбурі мозку та корі, ще менше його - в спинному мозку та мозочку. Також його знайдено в ендотелії дрібних кровоносних судин та в опасистих клітинах. Синтез гістаміну здійснюється в головному мозку шляхом декарбоксилування L-гістидину гістидиндекарбоксилазою. Свої ефекти він здійснює через два типи постсинаптичних рецепторів - Н1 і Н2. Синтез і викид даної речовини контролюється пресинаптичними ауторецепторами (Н3 рецептори). Означені рецептори дифузно розповсюджені у всіх відділах ЦНС. Було встановлено, що гістамін приймає участь в контролі функцій гіпофізу (викид гормонів, таких як пролактин, вазопресин та адренокортикотропний гормон), в обміні речовин мозку, регуляції бадьорості, харчової поведінки. Дослідження також показали, що вестибулярна система багато інервована гістамінергічними нейронами, - i вестибулярна функція та процеси вестибулярної компенсації здійснюються за участю нейротрансмісії гістаміну. Тобто існує функціональний зв'язок між гістамінергічною системою та центральними вестибулярними провідними шляхами. ВГ також відповідає за прояви вегетативних реакцій, за рахунок гістамінергічних шляхів від вестибулярних ядер до нейровегетативних центрів стовбура головного мозку. Саме цим пояснюються симптоми нудоти, блювоти, гіпергідрозу тощо, що супроводжують захворювання вестибулярного аналізатора. 
Серотонін $(\mathrm{CH})$ в ЦНС відіграє роль медіатора синаптичної передачі нервових імпульсів. Він синтезується специфічною системою нейронів, рухається по аксонах, досягає їх термінальних частин i, вивільнюючись, взаємодіє із серотонінергічними рецепторами інших нейронів. Основна кількість нейронів, які здатні синтезувати серотонін, знаходиться в 9 ядрах шва (nuclei raphe), що розміщені в центральній частині середнього і довгастого мозку. Нейрони названих ядер та їх аксони розглядають як специфічну серотонінергічну систему мозку. Концентрація СН відрізняється у різних відділах ЦНС: найбільша - в області гіпоталамусу та середнього мозку, дещо менше його в таламусі, гіпокампі, мозочку і сірій речовині спинного мозку. У великій кількості $(22,8$ мкг/Г) виявляли $\mathrm{CH}$ в епіфізі, притому в денний час найбільші концентрації, а в нічний час - найменші. D-серотонінергічні рецептори, які блокуються диетиламідом лізергінової кислоти та дибензиліном, локалізуються, в основному, в гладеньких м 'язах внутрішніх органів. Взаємодія CH 3 D-рецепторами супроводжується скороченням гладеньких м'язів. Мсеротонінергічні рецептори які здатні блокуватися морфіном та деякими іншими речовинами, розміщені, головним чином, у вегетативних гангліях. Впливаючи на ці рецептори, СН здійснює гангліостимулюючий ефект. Тсеротонінергічні рецептори блокуються типіндолом. Вони розміщені в серцеволегеневій рефлексогенній зоні і саме через них $\mathrm{CH}$ здійснює коронарний і легеневий хеморефлекси. У ЦНС виявлені D- та М- рецептори, існує думка про наявність в головному мозку i Т-серотонінергічних рецепторів. Одним із біологічних механізмів підтримання в організмі оптимального рівня фізіологічно активного СН є серотонінопексія. Суть цього феномена полягає у зв'язуванні ВС білками плазми крові і деякими клітинами. Зв'язаний СН втрачає свою фізіологічну активність. Основними білками плазми крові, які здатні зв'язувати ВС є альбуміни. Опасисті клітини, клітини легеневої тканини, еритроцити, тромбоцити, гепатоцити також здатні зв'язувати ВC, але природа i механізми цього процесу відрізняються від зв'язування з білками. Підвищення рівня ВС при анемії може також свідчити як про блокування процесів 
інактивації ВС, так і про посилене його вивільнення із депо. За збільшенням ступеню вивільнення біогенних амінів із депо можна робити висновки про наростання метаболічного ацидозу. Серотонінергічна система мозку бере участь у регуляції загального рівня активності ЦНС, циклів сну і бадьорості, загальної рухливої активності, емоційної поведінки, процесів пам'яті та навчання. При цьому важливим моментом $є$ взаємодія серотонінергічної системи мозку 3 іншими нейромедіаторними системами, насамперед, норадренергічною. Приймаючи участь в регулюванні емоційного стану, СН відіграє значну роль в формуванні емоційної пам'яті. Прийом триптофана, який $\epsilon$ основним джерелом для синтезу $\mathrm{CH}$, спричинює поглиблення сну i зменшення рухової активності у людини. Серотонінінергічна система мозку приймає участь у регуляції сексуальної поведінки. Підвищення рівня $\mathrm{CH}$ у мозку супроводжується пригніченням статевої активності. Серотонінергічна система мозку приймає участь у регуляції больової чутливості. Остання зменшується при збільшенні вмісту СН в ЦНС, а за пригнічення його синтезу в мозку - збільшується. Згідно з експериментальними даними, вплив СН на серцево-судинну систему полягає у змінах серцевого ритму і артеріального тиску, причому зміни останнього мають фазний характер: гіпотензія, яка виникає після введення $\mathrm{CH}$, змінюється гіпертензією, а після того знову розвивається гіпотензія. Це пояснюють тим, що на тонус судин СН здійснює як пряму, безпосередню дію, так і рефлекторну. На травний тракт $\mathrm{CH}$ впливає через посилення секреції пепсина і муцина слизовою оболонкою шлунка та перистальтики кишечника. Вплив СН на функції багатьох ендокринних залоз обумовлено, очевидно, не тільки його безпосередньою дією, але й центральними механізмами. СН бере участь у процесах гемостазу, оскільки вивільнення депонованого в тромбоцитах СН супроводжується їх агрегацією $\mathrm{i}$ спазмом ушкодженої судини. СН підвищує тромбопластичну активність, активність II, V, VI факторів зсідання крові. На дихальну систему СН впливає посилюючи бронхоспазм та змінюючи кровообіг у судинах легень та частоту дихання. Роль СН у регуляції функцій периферичної нервової системи (ПНС) $є$ 
мало вивченою. Однак відомо, що СН посилює передачу нервових імпульсів у вегетативних гангліях, а також підвищує їх реакції на подразнення струмом прегангліонарних волокон і введення гангліостимулюючих речовин, наприклад, ацетилхоліну. Дані розлади посилюють існуючу гіпоксію тканини мозку, супроводжуються метаболічними змінами та порушенням функціонування ЦНС та ПНС.

Певну негативну роль у розвитку патогенетичних порушень, відіграє також активація симпато-адреналової системи, мембранні та імунні зміни, які полягають у підвищенні активності перекисного окиснення ліпідів, пригніченні AOC, порушенні проникності та сорбційної спроможності мембран еритроцитів, зменшенні інсуліндепонуючої функції еритроцитів, дисфункції імунної системи.

Згідно думки С. В. Оковитого i А. В. Смирнова (2005) структура фармакологічних препаратів, що спричинюють антигіпоксичну дію може бути представлена наступним чином: інгібітори окислення жирних кислот; сукцинатвмісні i сукцинатутворюючі препарати; природні компоненти дихальних ланцюгів; штучні редокс-системи; макроергічні сполуки [22, 27]. Застосування антигіпоксантів і антиоксидантів при анемічній гіпоксії має добрі перспективи, оскільки вони нормалізують саму основу життєзабезпечення клітини - iї енергетику, яка визначає решту функцій.

Ми вивчали показники периферичної крові, параметри обміну заліза в плазмі крові у пацієнтів із анемією злоякісного новоутворення (АЗН) при пухлинних новоутвореннях товстого кишечника. Матеріалом для дослідження служила кров 96 пацієнтів (64 чоловіків і 32 жінок) із новоутвореннями товстого кишечника, серед яких було 39 пацієнтів (28 чоловіків та 11 жінок), перебіг основного захворювання у яких не супроводжувався наявністю анемії (перша (I) група спостереження) та 57 пацієнтів (36 чоловіків та 21 жінок), перебіг основного захворювання у яких обтяжувався АЗН (друга (II) група спостереження). Окремо обстежили 45 пацієнтів (19 чоловіків і 26 жінок) із залізодефіцитною анемією (ЗДА), причиною розвитку якої були хронічні 
крововтрати (третя (III) група спостереження). Вік обстежених від 22 до 69 років. Усі пацієнти були обстежені після верифікації діагнозу і до початку призначення будь-якого лікування.

Ступінь тяжкості перебігу анемії визначали за критеріями запропонованими Національним інститутом раку (США) і виділяли: легкий ступінь анемії - гемоглобін 10 - 12 г/дл; середньо тяжкий -8 - 10 г/дл; тяжкий - 6,5 - 8 г/дл; такий, що загрожує життю - нижче 6,5 г/дл. Легкий ступінь тяжкості перебігу АЗН діагностували у 29 хворих, середній - у 12, тяжкий - у 10 осіб, такий, що загрожує життю - у 6. У пацієнтів із ЗДА, відповідно, легкий у 19, середній у 14, тяжкий у 7 і такий, що загрожує життю - у 5 осіб.

Контрольну групу склали 50 здорових первинних донорів, які не мали в анамнезі вказівок на онкологічні чи хронічні запальні захворювання. Визначали вміст заліза в сироватці (C3) крові і показник загальної залізозв'язуючої здатності сироватки (33С) батофенантроліновим методом. Показник ненасиченої залізозв'язуючої здатності сироватки (Н33С) вираховували як різницю між 33С і С3. Коефіцієнт насичення трансферину залізом (КНТЗ) визначали як співвідношення вмісту С3 до З3С. Вміст трансферину (ТФ) визначали за показником 33С, феритину $(\Phi \mathrm{H})$ - радіометричним методом.

У пацієнтів із пухлинами кишечника проводили ретельне гістологічне дослідження препаратів, при цьому враховували характер меж пухлини 3 оточуючими тканинами, виразність інфільтрації, наявність пухлинних клітин у судинах, число мітозів, в тому числі атипових. Окрім означеного, визначали в пухлинах клітинні елементи різного ступеню зрілості (в \%) - низько диференційовані (НД), помірно диференційовані (ПД), високо диференційовані (ВД) клітини. За загально прийнятими критеріями оцінювали ступінь злоякісності та гістологічний тип пухлини.

Результати досліджень статистично опрацьовані за відповідними програмами. Достовірність різниці оцінювали, використовуючи коефіцієнт відмінності Ст'юдента $(\mathrm{p}<0,05)$. 
Як показав аналіз результатів дослідження периферичної крові у обстежених, концентрації гемоглобіну у пацієнтів II і III груп був достовірно меншим, ніж у контрольній та I групах $(\mathrm{p}<0,001)$. У контрольній групі цей

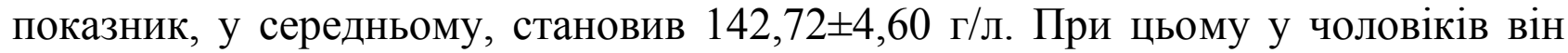
становив 146,72士4,60 г/л, при індивідуальних коливаннях від 135 до 164 г/л, а у жінок - 131,06+3,77 г/л, при індивідуальних коливаннях від 125 до 147 г/л. Показник концентрації гемоглобіну у чоловіків був вищим, ніж у жінок $(\mathrm{p}<0,001)$, в той же час у пацієнтів II і III груп ми не встановили достовірних відмінностей показника концентрації гемоглобіну залежно від статі (p>0,05).

Показник кількості еритроцитів у контрольній групі, у середньому, становив 4,76 $\pm 0,15 \times 10^{12} /$ л. При цьому даний показник у чоловіків, $\mathrm{y}$

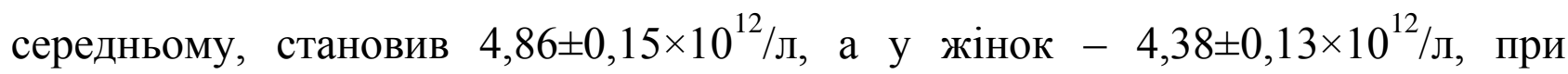
індивідуальних коливаннях у чоловіків - від 4,4 до $5,0 \times 10^{12} /$ л, а у жінок - від 4,2 до 4,7× $10^{12} /$ л. Кількість еритроцитів у чоловіків контрольної групи була більша, ніж у жінок $(\mathrm{p}<0,001)$. У той же час у пацієнтів II i III груп ми не встановили достовірних відмінностей показника кількості еритроцитів залежно від статі (p>0,05).

Показник кількості лейкоцитів у чоловіків контрольної групи, у середньому, становила $5,85 \pm 1,24 \times 10^{9} / л$, при індивідуальних коливаннях від 3,9 до $7,3 \times 10^{9} /$ л, а у жінок $-5,83 \pm 1,32 \times 10^{9} /$ л, при індивідуальних коливаннях від 3,8 до $8,3 \times 10^{9} /$ л. Ми не встановили достовірних відмінностей даного показника у групах обстежених поріняно із контролем, як і відмінностей залежно від статі $(\mathrm{p}>0,05)$.

Кількість тромбоцитів у контрольній групі, у середньому, становила $203,40 \pm 13,94 \times 10^{9} / л$. При цьому даний показник у чоловіків, у середньому,

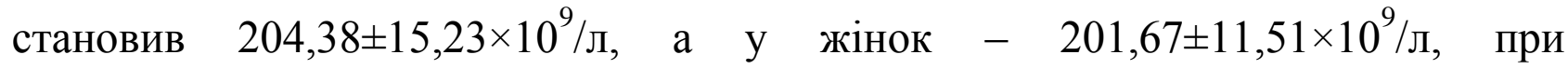
індивідуальних коливаннях у чоловіків - від 180 до $230 \times 10^{9} /$ л, а у жінок - від 190 до $220 \times 10^{9} /$ л. Порівняльний аналіз даного показника показав, що він був 
вищим у пацієнтів II і III груп порівняно із контролем ( $<00,001)$. Даний факт, можливо, підтверджує думку про наявність явних чи прихованих кровотеч у пацієнтів II i III груп із компенсаторним посиленням кровотворення у мієлоцитарному паростку, зокрема, тромбоцитопоезу.

Показник кількості ретикулоцитів у контрольній групі, в середньому, становив $0,88 \pm 0,05 \%$, у чоловіків - $0,87 \pm 0,05$, а у жінок $-0,88 \pm 0,04 \%$. Нами встановлено, що у пацієнтів II групи даний показник був достовірно нижчим, ніж у контрольній, I і III групах обстежених ( $<<0,001)$, що можна, на наш погляд, пояснити пригніченням еритропоезу у пацієнтів із АЗН дією гуморальних чинників та інтоксикаційним синдромом.

Показник МСН у контрольній групі, в цілому, становив $(30,63 \pm 0,25)$ пг, при коливанні показника від 27 до 33 пг. У жінок даний показник, в середньому, складав $(29,40 \pm 0,42)$ пг, при індивідуальних коливаннях від 27 до 31 пг, а у чоловіків, відповідно - $(31,13 \pm 0,24)$ пг, при індивідуальних коливаннях від 28 до 33 пг. Достовірних відмінностей показника $\mathrm{MCH}$ у обстежених цієї групи залежно від статі не виявлено (p>0,05). Порівняльний аналіз даного показника показав, що він був нижчим у пацієнтів II і III груп порівняно із контролем ( $<0,001)$. Даний факт свідчить про наявність порушень синтезу гемоглобіну і дефіциту заліза у пацієнтів II i III груп. Можна припустити, що у III групі обстежених він виникає за рахунок хронічних крововтрат, а у пацієнтів II групи, очевидно, за рахунок підвищення рівня прозапальних інтерлейкінів і гепсидину.

Показник MCV у контрольній групі, в цілому, становив $(93,41 \pm 0,91) \mathrm{fl}$, при коливанні показника від від 84 до $97 \mathrm{fl}$. У жінок означений показник, в середньому, складав $(94,22 \pm 1,69)$ fl при індивідуальних коливаннях від 89 до 97 fl, а у чоловіків, відповідно - $(92,29 \pm 1,01)$ fl, при індивідуальних коливаннях від 84 до 96 fl. Достовірних відмінностей показника MCV у I групі, порівняно 3 контрольною, нами не виявлено ( $>0,05)$, в той же час встановили зниження показника у пацієнтів II і III груп (p<0,001). 
Показник МСНС у контрольній групі, в цілому, становив $(34,38 \pm 0,23) \%$, при коливанні показника від 33 до 35 \%. У жінок показник МСНC, в середньому, складав $(34,35 \pm 0,31) \%$ при індивідуальних коливаннях від 33 до $35 \%$, а у чоловіків, в середньому, - $(34,41 \pm 0,41) \%$, при індивідуальних коливаннях показника від 33 до 35 \%. Достовірних відмінностей показника MCHC у пацієнтів I групи порівняно із контрольною, нами не виявлено ( $>00,05)$. Ми встановили зниження показника МCHC у пацієнтів II і III груп $(\mathrm{p}<0,001)$, що відображає наявність порушень обміну заліза і процесів еритропоезу та синтезу гемоглобіну.

Щодо основних показників обміну заліза у обстежених, дані наведені в табл. 1.

Таблиия 1

Основні показники обміну заліза у обстежених $(\mathrm{M} \pm \mathrm{m})$

\begin{tabular}{|c|c|c|c|c|c|}
\hline $\begin{array}{c}\text { Показник, } \\
\text { одиниця } \\
\text { виміру }\end{array}$ & \multicolumn{4}{|c|}{ Групи обстежених, кількість (n) } & Достовірність \\
\cline { 2 - 5 } & $\begin{array}{c}\text { Контрольна } \\
(\mathrm{n}=50)\end{array}$ & $\begin{array}{c}\text { Перша (I) } \\
(\mathrm{n}=39)\end{array}$ & $\begin{array}{c}\text { Друга (II) } \\
(\mathrm{n}=57)\end{array}$ & $\begin{array}{c}\text { Третя (III) } \\
(\mathrm{n}=45)\end{array}$ & $\begin{array}{c}\text { різниці } \\
(\mathrm{p})\end{array}$ \\
\hline $\begin{array}{c}\text { 3С, } \\
\text { мкмоль/л }\end{array}$ & $20,04 \pm 2,03$ & $20,75 \pm 1,94$ & $15,77 \pm 1,53$ & $8,47 \pm 0,69$ & $\mathrm{p}_{1}>0,05$ \\
& & & & & $\mathrm{p}_{2}<0,001$ \\
& & & & & $\mathrm{p}_{3}<0,001$ \\
& & & & & $\mathrm{p}_{4}<0,001$ \\
& & & & & $\mathrm{p}_{5}<0,001$ \\
\hline 333С, & $57,25 \pm 2,49$ & $56,52 \pm 2,37$ & $68,55 \pm 2,20$ & $88,75 \pm$ & $\mathrm{p}_{1}>0,05$ \\
& & & & & $\mathrm{p}_{2}<0,001$ \\
& & & & & $\mathrm{p}_{3}<0,001$ \\
& & & & & $\mathrm{p}_{4}<0,001$ \\
& & & & & $\mathrm{p}_{5}<0,001$ \\
\hline
\end{tabular}




\begin{tabular}{|c|c|c|c|c|c|}
\hline $\begin{array}{c}\text { НЗЗС, } \\
\text { мкмоль/л }\end{array}$ & $37,21 \pm 4,31$ & $36,77 \pm 4,07$ & $39,78 \pm 3,53$ & $\begin{array}{c}80,28 \pm \\
\pm 1,19\end{array}$ & $\begin{array}{l}\mathrm{p}_{1}>0,05 \\
\mathrm{p}_{2}<0,001 \\
\mathrm{p}_{3}<0,001 \\
\mathrm{p}_{4}<0,001 \\
\mathrm{p}_{5}<0,001\end{array}$ \\
\hline НТ3, \% & $35,18 \pm 4,90$ & $36,88 \pm 4,74$ & $32,17 \pm 3,63$ & $\begin{array}{l}9,54 \pm \\
\pm 0,43\end{array}$ & $\begin{array}{l}\mathrm{p}_{1}>0,05 \\
\mathrm{p}_{2}<0,001 \\
\mathrm{p}_{3}<0,001 \\
\mathrm{p}_{4}<0,001 \\
\mathrm{p}_{5}<0,001\end{array}$ \\
\hline $\begin{array}{c}\text { ТФ } \\
\text { сироватки, } \\
\text { г/л }\end{array}$ & $3,23 \pm 0,10$ & $2,90 \pm 0,09$ & $2,78 \pm 0,09$ & $\begin{array}{l}4,02 \pm \\
\pm 0,23\end{array}$ & $\begin{array}{l}\mathrm{p}_{1}<0,05 \\
\mathrm{p}_{2}<0,001 \\
\mathrm{p}_{3}<0,001 \\
\mathrm{p}_{4}<0,001 \\
\mathrm{p}_{5}<0,001\end{array}$ \\
\hline $\begin{array}{c}\text { ФН } \\
\text { сироватки, } \\
\text { мкг/л }\end{array}$ & $43,92 \pm 7,75$ & $86,91 \pm 9,14$ & $134,19 \pm 11,11$ & $\begin{array}{l}8,03 \pm \\
\pm 1,98\end{array}$ & $\begin{array}{l}\mathrm{p}_{1}<0,05 \\
\mathrm{p}_{2}<0,001 \\
\mathrm{p}_{3}<0,001 \\
\mathrm{p}_{4}<0,001 \\
\mathrm{p}_{5}<0,001\end{array}$ \\
\hline
\end{tabular}

Примітка: $\mathrm{p}_{1}$ - достовірність різниці між показниками контрольної групи i I групи; $p_{2}$ - достовірність різниці між показниками контрольної групи і II групи; $p_{3}$ - достовірність різниці між показниками контрольної групи і III 
групи; $\mathrm{p}_{4}$ - достовірність різниці між показниками у I і II групах; $\mathrm{p}_{5}-$ достовірність різниці між показниками у II і III групах.

Iз наведених у табл. 1 даних видно, що вміст ЗС у групі контролю, у середньому, становив 20,04 $\pm 2,03$ мкмоль/л. Даний показник у обстежених

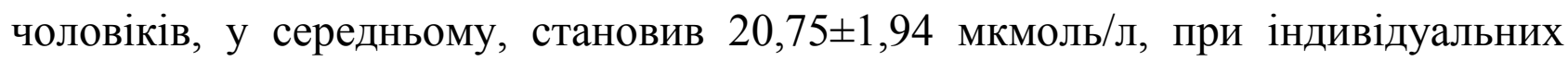

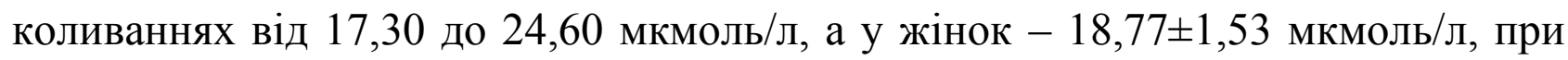
індивідуальних коливаннях від 16,40 до 21,30 мкмоль/л. Вміст ЗС у чоловіків контрольної групи був більшим, ніж у жінок $(\mathrm{p}<0,01)$. Із результатів нашого дослідження видно, що у пацієнтів II і III груп мало місце достовірне зниження показника вмісту $3 \mathrm{C}(\mathrm{p}<0,001)$.

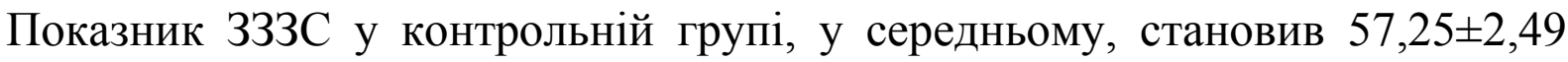
мкмоль/л. У чоловіків, у середньому, становив 56,52 $\pm 2,37$ мкмоль/л, а у жінок $58,55 \pm 2,20$ мкмоль/л, при індивідуальних коливаннях у чоловіків - від 52,05 до 61,03 мкмоль/л, а у жінок - від 54,87 до 62,05 мкмоль/л. Показник 333С у жінок контрольної групи був більшим, ніж у чоловіків $(\mathrm{p}<0,01)$. Нами встановлено, що у пацієнтів II і III груп показник 333С був достовірно нижчим, що відображає наявність порушень обміну заліза ( $<<0,001)$.

Показник НЗ3С у чоловіків контрольної групи, у середньому, становив $35,77 \pm 4,07$ мкмоль/л, при індивідуальних коливаннях від 28,05 до 43,37 мкмоль/л, а у жінок - 39,78 $\pm 3,53$ мкмоль/л, при індивідуальних коливаннях від 34,18 до 45,65 мкмоль/л. В цілому у групі контролю показник НЗ3С становив $37,21 \pm 4,31$ мкмоль/л, у жінок він був вищим, ніж у чоловіків (p<0,01). Як показав аналіз отриманих нами результатів, у пацієнтів II і III груп показник Н33С був достовірно більшим, що відображає наявність порушень обміну заліза $(\mathrm{p}<0,001)$.

Показник НТЗ у групі контролю, у середньому, становив $35,18 \pm 4,90$ \%. У чоловіків даний показник, у середньому, становив $36,88 \pm 4,74$ \%, а у жінок - 
$32,17 \pm 3,63 \%$, при індивідуальних коливаннях у чоловіків - від 28,60 до 46,10 $\%$, а у жінок - від 26,40 до $38,30 \%$. Показник НТ3 у чоловіків контрольної групи був більшим, ніж у жінок ( $<<0,01)$. Нами встановлено, що у пацієнтів II i III груп показник НТЗ був достовірно нижчим, що підтверджує наявність порушень обміну заліза ( $<<0,001)$.

Вміст ТФ у сироватці крові в контрольній групі, у середньому, становив $3,23 \pm 0,10$ г/л. У чоловіків даний показник, у середньому, становив $3,20 \pm 0,09$ г/л, а у жінок - 3,28 $\pm 0,09$ г/л, при індивідуальних коливаннях у чоловіків - від 2,23 до 3,38 г/л, а у жінок - від 2,24 до 3,42 г/л. Вміст ТФ у сироватці крові у жінок контрольної групи був більший, ніж у чоловіків $(\mathrm{p}<0,01)$. Як показав аналіз отриманих нами результатів, у пацієнтів II і III груп зміни показника ТФ, порівняно із контролем, мали різнонаправлений характер, у пацієнтів II групи він достовірно меншим, а у пацієнтів III групи достовірно більшим $(p<0,001)$. Такий характер змін свідчить про порушення синтезу і обміну ТФ в умовах пухлинної інтоксикації.

Показник вмісту ФН у сироватці крові обстежених контрольної групи чоловіків, у середньому, становив 24,91 $\pm 2,14$ мкг/л, при індивідуальних

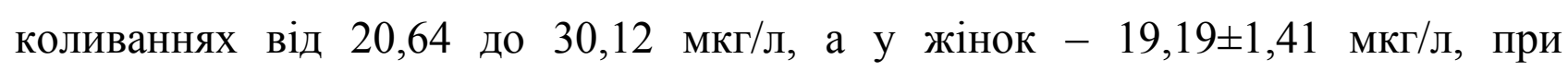
індивідуальних коливаннях від 17,15 до 21,82 мкг/л. В цілому, у контрольній

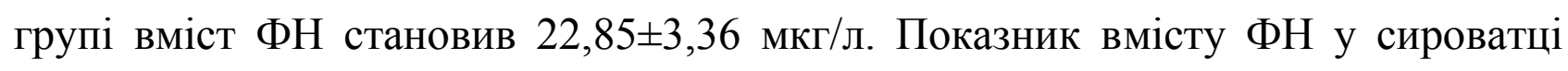
крові чоловіків даної групи був більший, ніж у жінок $(p<0,001)$. Нами встановлено, що у пацієнтів II і III груп зміни показника ФН, порівняно із контролем, також мали різнонаправлений характер, у пацієнтів II групи він достовірно більшим, а у пацієнтів III групи достовірно меншим $(p<0,001)$. Такий характер змін обумовлений тим, що ФН є білком гострої фази і в умовах пухлинної інтоксикації його рівень закономірно зростає. 
Цілком закономірно, що аналізуючи отримані дані, ми вважали за необхідне дослідити як змінюється показник ФН у хворих із супутньою АЗН, залежно від виразності анемічного синдрому. Дані представлені у табл. 2.

Таблиця 2

Показник вмісту феритину у сироватці крові хворих на пухлинні захворювання товстого кишечника із супутньою АЗН залежно від ступеню виразності анемії $(\mathrm{M} \pm \mathbf{m})$, мкг/л

\begin{tabular}{|c|c|c|}
\hline \multicolumn{2}{|c|}{ Групи обстежених, (n) } & \multirow{2}{*}{ Достовірність різниці (p) } \\
\hline Контрольна $(\mathrm{n}=50)$ & $\begin{array}{l}\text { із супутньою АЗН } \\
(\mathrm{n}=57)\end{array}$ & \\
\hline \multirow[t]{3}{*}{$43,92 \pm 7,75$} & $\begin{array}{l}\text { легкий перебіг анемії (n=29) } \\
88,98 \pm 11,15\end{array}$ & $\begin{array}{l}\mathrm{p}_{1}<0,05 \\
\mathrm{p}_{2}>0,05 \\
\mathrm{p}_{4}>0,05 \\
\mathrm{p}_{5}<0,05 \\
\mathrm{p}_{6}<0,001\end{array}$ \\
\hline & $\begin{array}{l}\text { анемія середнього ступеня } \\
\text { важкості }(\mathrm{n}=12) \\
122,89 \pm 15,87\end{array}$ & $\begin{array}{l}\mathrm{p}_{1}<0,05 \\
\mathrm{p}_{2}<0,05 \\
\mathrm{p}_{3}>0,05 \\
\mathrm{p}_{5}<0,05 \\
\mathrm{p}_{6}<0,01\end{array}$ \\
\hline & $\begin{array}{l}\text { тяжкий перебіг анемії (n=10) } \\
134,19 \pm 14,19\end{array}$ & $\begin{array}{l}\mathrm{p}_{1}<0,05 \\
\mathrm{p}_{2}<0,05 \\
\mathrm{p}_{3}<0,05 \\
\mathrm{p}_{4}<0,05 \\
\mathrm{p}_{6}<0,01\end{array}$ \\
\hline
\end{tabular}




\begin{tabular}{|l|l|c|}
\hline анемія, що загрожус життю (n=6) & $\mathrm{p}_{1}<0,01$ \\
$143,28 \pm 7,11$ & $\mathrm{p}_{2}<0,01$ \\
& $\mathrm{p}_{3}<0,05$ \\
& $\mathrm{p}_{4}<0,01$ \\
& $\mathrm{p}_{5}<0,01$ \\
\hline
\end{tabular}

Примітка: p $_{1}$ - достовірність різниці порівняно із контрольною групою;

$\mathrm{p}_{2}$ - достовірність різниці із пацієнтами II групи; $\mathrm{p}_{3}$ - достовірність різниці iз пацієнтами, які мали легкий перебіг анемії; p $_{4}$ - достовірність різниці із пацієнтами, які мали середній перебіг анемії; $\mathrm{p}_{5}$ - достовірність різниці із пацієнтами, які мали тяжкий перебіг анемії; p 6 - достовірність різниці із пацієнтами, які мали перебіг анемії, що загрожує життю.

Як видно із наведених у табл.2 даних, у хворих на пухлинні захворювання товстого кишечника із супутньою АЗН, показник вмісту ФН у сироватці крові збільшується пропорційно зростанню ступеня тяжкості перебігу анемії. Тобто, ступінь перебігу анемії, що загрожує життю при АЗН у пацієнтів супроводжується найвиразнішим збільшенням вмісту ФН у сироватці крові, що очевидно, є відображенням особливостей його обміну при пухлинному процесі.

У клінічній практиці показник вмісту ФН широко використовують для оцінки депонування заліза. Загальновідомо, що зменшення рівня ФН в сироватці крові є ранньою ознакою латентного дефіцита заліза. У комплексі із змінами інших параметрів заліза він може свідчити за наявність ЗДА. Різке зростання ФН в сироватці крові може свідчити за гемохроматоз чи посттрансфузійний гемосидероз. Нормальний рівень ФН в сироватці при наявності сидеропенічного i анемічного синдромів може свідчити про порушення процесів утилізації заліза в еритроїдних клітинах-попередницях [19]. 
Останнім часом виявлені інші фізіологічні функції $Ф Н$, які безпосередньо не пов'язані 3 обміном заліза. ФН може здійснювати цитотоксичний ефект по відношенню до ряду клітин, насамперед, мієлоїдних попередниць гранулоцитів, моноцитів. Встановлено, що процеси мієлосупресії скорельовані $з$ активізацією синтезу Н-субодиниць на рівні геному. Н-ФН здатний здійснювати блокування проліферації, як мієлоїдних так і лімфоїдних клітин. Існує думка, що цей процес може мати захисне значення для упередження злоякісного росту. Механізм пригнічення ФН проліферації клітин пов'язують з його ферооксидазними властивостями. Процес окислення заліза 3 $\mathrm{Fe}^{2+}$ до $\mathrm{Fe}^{3+}$ супроводжується перенесенням електрона на молекулярний кисень, утворенням різних радикалів кисню, які є цитотоксичними агентами. Інгібірування проліферації відбувається на рівні S-фази клітинного циклу. Цікаво, що ФН супресує нормальні мієлоїдні клітини-попередниці і не супресує клітини-попередниці хворих на лейкози. L-субодиниці $Ф Н$ не мають ферооксидазних і мієлосупресорних властивостей. Їм приписують функції стабілізаторів структури ФН.

Рівень ФН значно зростає при гострих запальних процесах, його розглядають, як гострофазовий протеїн, що має виразні цитотоксичні i цитотропні властивості. Рівень ФН у сироватці крові збільшується при наявності різного типу пухлин в організмі: раку яєчників, простати, підшлункової залози, легень, прямої кишки, гепатоцелюлярній карциномі тощо. Концентрація ФН підвищується і при різних захворюваннях печінки (гепатити, цироз, тощо), які супроводжуються деструкцією гепатоцитів. При цьому ФН безпосередньо вивільняється із клітин печінки, яка $є$ його депо. Отже, підвищення вмісту ФН в сироватці крові може бути як онкомаркером, так i ознакою захворювання печінки.

2.2 Pro- and antioxidant processes in the body under experimental enteropathology, their correction 
Peroxide oxidation of lipids is a physiological process, and abnormalities lead to undesirable consequences [28-30]. The lipid peroxidation system is a multi-stage chain mechanism, which is activated when various factors influence the body. In cells, the level of POL is maintained due to the balance of the pro- and antioxidant system. The latter is multicomponent, which includes both enzyme complexes and endogenous antioxidants [31]. It has been shown [32-35] that the use of additives to the feed - vitamins, mineral elements, antioxidants, herbal preparations and other biologically active substances (BAS) - stimulates the system antioxidant protection (AOP) of the organism and, in turn, contributes to its resistance, reproductive capacity, productivity. The BAS "FLP-MD", which contains phospholipids (PLs) milk, unsaturated fatty acids, retinol acetate and $\alpha$-tocopherol, has been developed and is effective when used in the complex treatment of calves that have recovered from neonatal dyspepsia [36, 37]. To determine the biological effect of the action of BAS "FLP-MD" it is important to study its effect on the intensity of the course of lipid peroxidation and the activity of antioxidant enzymes of various organs and cells.

Thus, prooxis-antioxidant state of liver cells, small intestine mucosa and blood under conditions of enteropathology and for the therapeutic effect of liposomal form of BAS "FLP-MD" have been studied.

The study was carried out on laboratory mongrel male rats weighing 200-220 g, from which three groups of 8 individuals were formed: I (control) - intact animals; II - reproduction of the model of enteropathology with ulcerative erosion [38]; III reproduction of the model of enteropathology and correction of pathological changes by applying liposomal form of BAS "FLP-MD" [39].

Various pathological states of the body are characterized by the activation of lipid peroxidation - a free-radical chain process, which leads to the formation of peroxides of organic and inorganic nature. It was found that under the conditions of the enteropathology model with ulcerative erosion, the content of thiobarbituric acid active products (TBA-active products) in the liver cells decreased insignificantly, and in the cells of the small intestine mucosa by $23 \%$. This may be due to the use of lipid 
peroxidation products in oxygen-containing organic compounds. Along with this, the content of TBA-active products in blood serum increases significantly (by 3.2 times), possibly as a result of their intake from other tissues.

Control over the formation and neutralization of metabolites of free radical oxidation and their products is carried out with the participation of the AOP of the body system, which leads to the maintenance of intracellular oxygenase reactions at the optimal steady-state level, which is a prerequisite for the realization of various physiological functions. In cells and biological fluids a physiological antioxidant system functions. The most important components of anti-radical and antiperoxide protection are enzymes that catalyze the reactions between the active forms of oxygen [31]. One of the key enzymes of the antioxidant defense system is superoxide dismutase (SOD) and katalase (Kat). The results obtained to determine the activity of SOD indicate that under the conditions of the model, the activity of the enzyme in the studied preparations is reduced, which for the liver is $23 \%$ (Table 1). The activity of Kat in liver and blood preparations is reduced by 10 and $45 \%$, respectively, and the small intestine grows by $24 \%$ under the conditions of the model. The growth of enzyme activity can be considered as a reaction of the AOP system of cells of the small intestinal mucosa to the intensification of the processes of free radical oxidation and the activation of many metabolic processes. According to the therapeutic use of dietary supplements, the activity indices of these enzymes in the studied preparations are almost not different from the control values, and the activity of blood Kat even exceeds them. The indicator of the content of TBA-active products in the studied preparations also almost returns to the control values.

However, in these conditions, in the preparations of the small intestine its activity increases by $200 \%$. Multidirectional changes were detected for the drugs under study and in the activity of glutathione transferase (GT): in the blood, the activity of the enzyme decreases by $41 \%$, and in liver and small intestine preparations it increases (by $21 \%$ for the latter). 
The parameters of lipid peroxidation of liver, small intestine mucosa and blood of experimental rats $(\mathrm{M} \pm \mathrm{m}, \mathrm{n}=8)$

\begin{tabular}{|c|c|c|c|}
\hline Research conditions & $\begin{array}{c}\text { TBA-active products, } \\
\mu \mathrm{mol} / \mathrm{mg} \text { protein }\end{array}$ & $\begin{array}{c}\text { SOD, } \\
\text { restored U/mg of } \\
\text { protein }\end{array}$ & $\begin{array}{c}\text { Kat, } \\
\mu \mathrm{mol} / \mathrm{min} \mathrm{mg} \text { of protein }\end{array}$ \\
\hline \multicolumn{4}{|c|}{ Liver } \\
\hline Control & $1.57 \pm 0.04$ & $292 \pm 0.25$ & $0.069 \pm 0.005$ \\
\hline Model & $1.41 \pm 0.05^{*}$ & $2.26 \pm 0.19^{*}$ & $0.062 \pm 0.003$ \\
\hline BAS «FLP-MD» & $1.55 \pm 0.09$ & $2.47 \pm 0.15$ & $0.085 \pm 0.006^{*}$ \\
\hline \multicolumn{4}{|c|}{ Small intestine } \\
\hline Control & $0.43 \pm 0.02$ & $2.59 \pm 0.15$ & $0.041 \pm 0.010$ \\
\hline Model & $0.33 \pm 0.04^{*}$ & $2.41 \pm 0.25$ & $0.051 \pm 0.011^{*}$ \\
\hline $\mathrm{BAS} « \mathrm{FLP}-\mathrm{MD} »$ & $0.41 \pm 0.04$ & $2.28 \pm 0.15$ & $0.037 \pm 0.008$ \\
\hline \multicolumn{4}{|c|}{ Blood } \\
\hline & $\mathrm{mmol} / \mathrm{l}$ & cond. U. & $\mu \mathrm{mol} / 1 \mathrm{~min}$ \\
\hline Control & $1.68 \pm 0.15$ & $1.67 \pm 0.08$ & $33.8 \pm 5.0$ \\
\hline Model & $5.29 \pm 0.18^{*}$ & $1.50 \pm 0.09$ & $18.5 \pm 6.3^{*}$ \\
\hline $\mathrm{BAS} \ll \mathrm{FLP}-\mathrm{MD} »$ & $2.36 \pm 0.10^{*}$ & $1.61 \pm 0.07$ & $65.2 \pm 2.1^{*}$ \\
\hline
\end{tabular}

Note: $\mathrm{p} *{ }_{-}<0.05$, relative to the reference values.

Along with this, the content of reduced glutathione (RG) drops sharply in blood preparations (by 92\%), and in preparations of the liver and small intestine by 19 and $14 \%$, respectively. Under conditions of therapeutic administration of dietary supplements, the activity of GT and glutathione peroxidase (GP) of blood approaches the control values, while for small intestine preparations there is an increase, compared with the control, of the activity of the corresponding enzymes. With the introduction of BAS "FLP-MD" in enteropathology conditions, the content of RG in the studied preparations remains significantly lower with respect to control (Table 2).

Table 2. 
The content of reduced glutathione and the activity of glutathione-dependent enzymes of liver preparations, small intestine mucosa and blood $(\mathrm{M} \pm \mathrm{m}, \mathrm{n}=8)$

\begin{tabular}{|c|c|c|c|}
\hline Research conditions & $\begin{array}{c}\mathrm{RG} \\
\mathrm{mM} / \mathrm{min} \mathrm{mg} \text { of protein }\end{array}$ & $\begin{array}{c}\text { GP } \\
\mu \mathrm{mol} / \mathrm{min} \mathrm{mg} \text { of } \\
\text { protein }\end{array}$ & $\begin{array}{c}\text { Restored glutathione, } \\
\mu \mathrm{mol} / \mathrm{mg} \text { protein }\end{array}$ \\
\hline \multicolumn{4}{|c|}{ Liver } \\
\hline Control & $0.365 \pm 0.012$ & $0.250 \pm 0.025$ & $0.994 \pm 0.015$ \\
\hline Model & $0.399 \pm 0.015$ & $0.235 \pm 0.019$ & $0.809 \pm 0.011^{*}$ \\
\hline BAS «FLP-MD» & $0.264 \pm 0.019^{*}$ & $0.294 \pm 0.015^{*}$ & $0.550 \pm 0.012^{*}$ \\
\hline \multicolumn{4}{|c|}{ Small intestine } \\
\hline Control & $0.079 \pm 0.009$ & $0.022 \pm 0.005$ & $0.766 \pm 0.010$ \\
\hline Model & $0.100 \pm 0.010^{*}$ & $0.044 \pm 0.007^{*}$ & $0.660 \pm 0011^{*}$ \\
\hline $\mathrm{BAS} \ll \mathrm{FLP}-\mathrm{MD} »$ & $0.071 \pm 0.008$ & $0.065 \pm 0.010^{*}$ & $0.530 \pm 0.018^{*}$ \\
\hline \multicolumn{4}{|c|}{ Blood } \\
\hline & $\mathrm{mmol} / \mathrm{min} \mathrm{dm}^{3}$ & $\mathrm{mmol} / 1 \mathrm{dm}^{3}$ & $\mathrm{mmol} / \mathrm{l}$ \\
\hline Control & $92.1 \pm 5.0$ & $0.440 \pm 0.018$ & $0.787 \pm 0.100$ \\
\hline Model & $54.0 \pm 4.8^{*}$ & $0.309 \pm 0.019^{*}$ & $0.070 \pm 0.013^{*}$ \\
\hline BAS «FLP-MD» & $63.2 \pm 3.8^{*}$ & $0.318 \pm 0.017^{*}$ & $0.089 \pm 0.002 *$ \\
\hline
\end{tabular}

Note: $\mathrm{p} *$ - $<0.05$, relative to the reference values.

Analyzing the received results it is necessary to note infringements of functioning of system AOP of an organism in conditions of model. However, the nature of these changes has features for various organs. This probably indicates a violation of the interaction of its functioning under these conditions. The greatest changes in the conditions of the model are observed for the studied blood indices. Under these conditions, TBA-active products accumulate in the blood, the content of RG and the activity of GT, as well as the activity of Kat and GP, accumulate, testifies to the oppression of the functioning of the OA-defense system of the organism. 
The decrease in enzymatic and non-enzymatic links of AOP in the liver in experimental animals indicates a suppression of SOD activity and a decrease in the content of RG. Under these conditions, the activity of enzymes responsible for the detoxification of peroxide compounds (Kat and GP) is also slightly reduced. For preparations of the small intestine, there is an increase in the activity of Kat and GP. At the same time, the activity of SOD varies insignificantly, and the decrease in the content of RG is observed along with the growth of GT activity. The therapeutic administration of BAS "FLP-MD" under conditions of enteropathology has different effects on the restoration of the studied parameters: the activity values of the AOP enzymes approach the control values or even grow (Kat of the liver and blood or GP of the liver and small intestine). However, under the conditions of treatment of BAS "FLP-MD", the content of RG remains below the control values. Since RG participates in many metabolic processes, a decrease in its content for the therapeutic effect of BAS "FLP-MD" may also indicate the activation of restorative processes in the body.

Thus, BAS "FLP-MD" has a protective effect on the course of oxidative processes under enteropathology, given that its main component is PLs, which on one hand stabilize the cell membranes, and on the other hand, are oxidized for the actions of oxygen radicals, that is, natural antioxidants.

\subsection{Choice of water for body health}

Water taken in sufficient quantity is of magor importance in disease prevention. We must recognize the vital importance of water and learn to recognize dehydration by identifying dysfunction of the organs in which pathological symptoms appear. MD F. Batmanghelidj devoted twenty years of his life to studying this subject and came to the unequivocal conclusion that the existence of different indicators "sustainable unintentional dehydration". The results of his research (more than 3 thousand patients were cured with water only for the first few years of observations) indicate that the human body has three categories of indicators that should be considered as symptoms 
or results of dehydration: sensitive indicators, water shortage alarms and adaptive programs to combat dehydration. These signals dehydration can be seen, recognized and even prevent their occurrence, before the body inflicted damage will be irreparable.

Water shortages emergency signals include various localized chronic pain. The origin of the pain and symptoms is easy to understand. They occur when any organ actively used at the moment face shortage of water to clean itself of "toxic waste", which are by-products of metabolism. Nerve endings register the change in chemical environment and transmit this information to the brain. Perceiving pain signals to the brain tries to report the threats that may be a result of local dehydration.

Thus, pain not caused by any infection or trauma is a signal of lack of water in the area where the pain is felt. Pain is owr body's desperate request of water, required to flush toxic wastes away from areas affected by dehydration. The main problem of today's most common mistakes is a lack of understanding of the significance and importance of pain as a tangible body thirst signal.

Water for the human's body is vital important to health and well-being. The assumption that taking any liquid, such as tea, juice, soup or milk will affect the way water does is false. Here is a new scientific truth and a new level of thinking that will help most people to use preventive medicine - water being the solvent regulates all body functions, including the activity of dissolved substances. Violation water metabolism sent many signals that indicate certain "problems in the system".

Adequate water consumption is useful for maintaining health and is essential to prevent dehydration, which is associated with adverse health effects such as headache, urolithiasis, cognitive disorders. Health risks (such as tooth decay, obesity) are associated with regular intake of high doses of calorie sweetened beverages (such as soda, fruit drinks, sports drinks) are reduced in their placement in ordinary drinking water. Consumption of water before meals and replacing high-calorie sweetened drinks with water correlate with lower energy consumption and increased intake of plain water with adult associats with keeping weight at a certain level or weight loss. According to the dietary recommendations for Americans 2010 adults 
should drink water as a remedy hydration and state medical organizations are recommended to pro this message in a society.

With age, the sharpness of thirst and awareness that the body requires water is lost. Chronic dehydration in the elderly can lead to heart disease and kidney disease. Those who have heart or kidney problems, who is undergoing treatment, water intake should be increased slowly and, if possible, under medical supervision. Urine developing should be increased simultaneously with the taken amount of water. If during the two days urination doesn't increase, you should consult your doctor. Those who have their heart and kidneys are function normally, should start with two glasses of water half an hour before each meal and a glass of water two and a half hours after the meal.

Experience shows that a person needs to drink 14 grams of water for every 450 g weight (in the metric system about $30 \mathrm{~g}$ per $1 \mathrm{~kg}$ ) a day. Increasing the receiving water causes increased production of urine, which can lead to loss of salt, minerals and water soluble vitamins. Therefore, an additional amount of salt (about half a teaspoon of salt per 2 liters of water you drink per day, it can be added to food) and vitamins should be added to the daily diet. If cramps appear, it means that the amount of salt in the diet is not enough to meet all the needs of the body. Then the amount of salt in the diet sould be increased for the entire period of increased water taking. Dehydration urine colour (if one does not take vitamins that can change the color of urine) varies from dark yellow to orange. The more the body is saturated with water, the lighter the urine is.

According to the study of a nationally representative sample of 3,397 American adults who participated in the survey of food attitudes and habits of the National Cancer Institute in 2007, $7 \%$ of adults reported no daily consumption of drinking water, $36 \%$ reported drinking 1 to 3 cups, $35 \%$ reported drinking 4 to 7 cups, and $22 \%$ reported drinking 8 glasses or more. Previous studies have shown that water consumption decreases with age; study of 4112 American adults by Kant and other authors found a reduced consumption of plain water among the elderly. 
According to the National research survey of health and nutrition 2005-2008 biennium (NHANES), a simple water consumption among American adults (aged $\geq 20$ years) was 4.4 cups for men and 4.3 cups for women. Few studies have been conducted on the relationship of individual water consumption practices and nutrition principles and diet. Although water consumption has been associated with individual factors (such as physical activity, which leads to increased needs for hydration due to sweating), little is known about how water consumption is associated with other food and health related habits and attitudes. There is evidence of cross-study habits and nutritionally (FAB) of National Cancer Institute, when the survey among American adults was conducted by post from October to December 2007. This study was approved by the Expert Council on nutrition National Cancer Institute. Results of multivariate regression analysis showed no association between consumption of water and TV watching timeV, which is consistent with a study conducted among 3,867 American children and adolescents. A well-known practice of encouraging smoking cessation program participants by increasing their water consumption.

Through regular use of water in sufficient quantity each person can help the body stay healthy for a long time.

Thus, only the awareness of the need to maintain health on a personal level, supported by the health system in the state and global scale can reduce the incidence of complications and prevent diseases. 


\section{SECTION 3. PHARMACY}

\subsection{The design of immunostimulants and adjuvants used for the treatment and prevention of animal diseases}

The problem of stimulation of immunogenesis in veterinary practice is relevant and has attracted the attention of immunologists. Currently, the scientists of many countries carried out extensive work on the design of Immunostimulants and adjuvants used in conjunction with vaccines for the treatment and prevention of animal diseases. More than 100 years is the search for compounds that would affect the formation of antibodies and contributed to the emergence of immune responses. With this goal constantly develop new and more effective biological, chemical and physical adjuvants and adjuvants.

Currently, a large number of substances which are able to exert adjuvant effect on various antigens. As adjuvants are used killed microorganisms (mycobacteria, corynebacteria, Nocardia, etc.), organic substances (bacterial polysaccharides and lipopolysaccharides, lecithin, cholesterol, lanolin, agar, glycerin, gelatin, starch, pectin, protamines, etc.), inorganic substances (aluminium hydroxide, aluminum phosphate, calcium chloride, calcium phosphate, iron hydroxide, ammonialyase alum, mineral oil, etc.), synthetic substances (nucleotides, polyanion, etc.). In addition to simple adjuvants, use complex, representing a mixture of lipids with mineral sorbents, oil with lipopolysaccharides and emulsifiers, micro-organisms from oils and other substances. The following is a classification of adjuvants on physicochemical and biological properties (tabl. 1) [56, 57].

Table 1

Classification of adjuvants

\begin{tabular}{|l|l|l|}
\hline Adjuvant & Adjuvant Characteristics & Advantages / Disadvantages \\
\hline
\end{tabular}




\begin{tabular}{|c|c|c|}
\hline Group & & \\
\hline 1 & 2 & 3 \\
\hline $\begin{array}{l}\text { Mineral } \\
\text { adjuvants }\end{array}$ & $\begin{array}{l}\text { The adjuvant properties of such } \\
\text { inorganic substances as aluminum } \\
\text { hydroxide gel (GOA), aluminum } \\
\text { phosphate, calcium phosphate, } \\
\text { silicon dioxide, and others have } \\
\text { been widely studied [2]. Mineral } \\
\text { adjuvants can provide a longer } \\
\text { process for the receipt of antigens } \\
\text { (depositing effect). }\end{array}$ & $\begin{array}{l}\text { The disadvantage of these } \\
\text { adjuvants is that aluminum } \\
\text { salts, due to the formation of } \\
\text { small granulomas in which the } \\
\text { adsorbed antigen is retained, } \\
\text { can trigger inflammatory } \\
\text { reactions. }\end{array}$ \\
\hline Oil adjuvants & $\begin{array}{l}\text { Type of adjuvants based on } \\
\text { mineral oils. Such preparations are } \\
\text { droplets of water with an antigen } \\
\text { dissolved in them, which are in the } \\
\text { oil phase. This type of emulsion is } \\
\text { called water in oil. The oil used is } \\
\text { highly purified liquid paraffin. In } \\
\text { addition to oil, an emulsifier must } \\
\text { be present to stabilize the mixture. } \\
\text { The opposite type of emulsion - } \\
\text { "oil in water" is a microdroplet of } \\
\text { oil in water, stabilized by } \\
\text { hydrophilic emulsifiers. This type } \\
\text { of emulsion provides a high level } \\
\text { of antigen presentation and } \\
\text { moderate antigen recognition, goes } \\
\text { well with lipophilic } \\
\text { immunomodulators [53]. }\end{array}$ & $\begin{array}{l}\text { The positive effect of } \\
\text { vaccination is achieved by the } \\
\text { fact that mineral oil is not } \\
\text { metabolized, due to which } \\
\text { drops of the emulsion with the } \\
\text { antigen inside them are kept at } \\
\text { the injection site for a long time } \\
\text { [58]. }\end{array}$ \\
\hline
\end{tabular}




\begin{tabular}{|c|c|c|}
\hline 1 & 2 & 3 \\
\hline $\begin{array}{l}\text { Natural } \\
\text { adjuvants }\end{array}$ & $\begin{array}{l}\text { Many natural compounds of } \\
\text { various origin have an adjuvant } \\
\text { effect: proteins, glycoproteins, } \\
\text { peptides, polysaccharides, etc. The } \\
\text { peculiarity of this group of } \\
\text { adjuvants is that they do not create } \\
\text { an antigen depot in the body and } \\
\text { directly stimulate the production of } \\
\text { antibodies. In recent years, } \\
\text { scientists from various countries } \\
\text { conducted a series of studies on the } \\
\text { use of chitosan and its derivatives } \\
\text { as part of veterinary vaccines as an } \\
\text { adjuvant. A number of works have } \\
\text { been carried out by foreign } \\
\text { scientists on the inclusion of } \\
\text { chitosan modifiers as adjuvants in } \\
\text { vaccines against listeriosis, } \\
\text { pseudomonosis, brucellosis, foot } \\
\text { and mouth disease, influenza and } \\
\text { other infections }\end{array}$ & $\begin{array}{l}\text { The use of chitosan as an } \\
\text { adjuvant allows you to get an } \\
\text { immune response to the } \\
\text { introduced antigens at or above } \\
\text { the immune response using } \\
\text { known oil and mineral } \\
\text { adjuvants, which indicates the } \\
\text { promise of further research in } \\
\text { this direction [55]. }\end{array}$ \\
\hline $\begin{array}{l}\text { Synthetic } \\
\text { adjuvants }\end{array}$ & $\begin{array}{l}\text { Muramyl dipeptide derivatives } \\
\text { (MDP) are most commonly used. } \\
\text { Muramyldipeptide promotes the } \\
\text { production of antibodies to } \\
\text { synthetic antigens. Due to its } \\
\text { toxicity, the efforts of researchers }\end{array}$ & $\begin{array}{l}\text { Its advantage is the relative } \\
\text { non-toxicity and the } \\
\text { manifestation of the adjuvant } \\
\text { action in both oil and water } \\
\text { solutions. }\end{array}$ \\
\hline
\end{tabular}




\begin{tabular}{|c|c|c|}
\hline & $\begin{array}{l}\text { are aimed at obtaining synthetic } \\
\text { analogues [2]. An example of such } \\
\text { analogs is N-acetyl-muramyl-L- } \\
\text { alanine-D-isoglutamine, which has } \\
\text { similar efficacy. }\end{array}$ & \\
\hline $\begin{array}{l}\text { Surfactant } \\
\text { Adjuvants } \\
\text { and Searches }\end{array}$ & $\begin{array}{l}\text { Saponin and Iskom are } \\
\text { immunomodulators capable of } \\
\text { stimulating Th } 1 \text { and Th } 2 \text { immune } \\
\text { responses. The vaccine adjuvants } \\
\text { mainly use partially purified or } \\
\text { specific fractions of QS } 21 \text { or } \\
\text { ISCOPREP saponin. Saponin } \\
\text { causes tissue damage and thereby } \\
\text { contributes to antigen retention at } \\
\text { the injection site [54]. }\end{array}$ & $\begin{array}{l}\text { The resulting complexes } \\
\text { have a higher immunogenicity } \\
\text { than the original proteins. } \\
\text { Since ISCOM are } \\
\text { microparticles, they are easily } \\
\text { absorbed by macrophages, } \\
\text { where they are processed and } \\
\text { presented [53]. }\end{array}$ \\
\hline Liposomes & $\begin{array}{l}\text { Microscopic structures } \\
\text { consisting of several concentric } \\
\text { lipid bimembrane structures } \\
\text { surrounded by water. They are } \\
\text { vesicles that are able to encapsulate } \\
\text { an antigen and act as a means of } \\
\text { delivery [58]. }\end{array}$ & $\begin{array}{l}\text { Liposomes carry out } \\
\text { directed transport of antigen to } \\
\text { the cells of the } \\
\text { reticuloendothelial system. } \\
\text { Numerous studies have proved } \\
\text { the ability to use liposomes not } \\
\text { only as carriers, but also as an } \\
\text { immunomodulator, having } \\
\text { discovered the } \\
\text { immunomodulating properties } \\
\text { of liposomes themselves. }\end{array}$ \\
\hline
\end{tabular}

At present, special attention is paid to environmentally friendly drugs immunostimulant. Feature of immunostimulating drugs is their high biological activity aimed at enhancing immunity and metabolic processes in animals, causing 
the animal organism itself gets rid of parasites. In addition, Immunostimulants favorably to Anthelmintics those that do not have side effects, do not accumulate in organs and tissues of the animal and not cause addiction from the parasites and do not pollute the environment. Thus, the correct application of immunostimulatory drugs not only safe, but is aa highly effective method of prevention and treatment of animal diseases and maintenance of their resistance to highlevel.

Today, there is a large selection of new commercial ready-made adjuvant and immunostimulating products, which are also at the development and testing stage, designed for different types of animals, aimed at initiating various types of immune responses, combining different levels of efficacy and safety indicators. Therefore, studies on the inclusion of various types of adjuvants in the composition of inactivated vaccines, as well as on the use of immunostimulants, are very relevant, they are conducted by most European companies involved in the production of biological products for veterinary medicine.

\subsection{Biopharmaceutical classification system as a tool for drug development}

With the growth of the pharmaceutical market and the level of drug consumption, the quality of medicines is an important aspect of effective care. Generics occupy a significant share in the growing market of medicines. Typically, generics have a lower cost. This is due to the lack of expenditure of companies of generic manufacturers to develop and study the original structure of the drug and conduct expensive clinical trials, as well as the much lower cost of bringing the replicated drug to market.

Biopharmaceutical studies are aimed at studying the relationship between medicine as a chemical system and macroorganism as a biological system. The aim of these studies is to find ways to increase the therapeutic activity of drugs and reduce their side effect, taking into account pharmaceutical factors. The term "pharmaceutical factors" was widely used when experimental data on the significant 
dependence of LP effectiveness on methods of obtaining them were confirmed in the clinic. However, the concept of "pharmaceutical factors" in the modern scientific literature does not apply to literally all the processes that occur when receiving drugs, but only to those for which their effect on the therapeutic activity of the drug has already been indisputably established. This follows the recognition of biological, medical significance behind all processes of manufacture and prescribing of drugs, ranging from its synthesis, the choice of a chemical variant (salt, ether, etc.), the use of the appropriate polymorphic form and ending with the choice of drug form and pathways of introduction [59-61].

Section 1. Biopharmaceutical and pharmaco-technological aspects of drug development

The problem of interchangeability of LS is one of the most controversial topics, and it is quite acute due to the large number of drugs of various manufacturers on the market. Generic is useful for both the patient and the health care if it is fully equivalent to the original drug and has the best pharmacoeconomic characteristics. Compliance with the effectiveness and safety of innovative and replicated drugs ensures their interchangeability in clinical practice, i.e. therapeutic equivalence. Drug interchangeability is determined on the basis of the following six parameters:

1) Equivalence of the qualitative and quantitative characteristics of pharmaceutical substances;

2) the equivalence of the drug form;

3) the equivalence or comparability of auxiliary substances;

4) Identity of the method of introduction and application;

5) No clinically significant differences in the study of bioequivalence or therapeutic equivalence;

6) Good Manufacturing Practice (GMP) compliance with the manufacturer's good manufacturing practice (GMP).

Comparing replicated and referenced drugs, it is necessary first of all to establish their therapeutic and biological equivalence. Therapeutic equivalence refers to the identification of the same properties of drugs of a certain form of drugs, as well 
as the presence of the same indicators of the safety and effectiveness of drugs, the same clinical effects in their use. Biological equivalence is defined by the determination of the rate of absorption and excretion of one or more pharmacologically active substances, as well as the amount of drug reaching systemic blood flow $[62,63]$.

In addition, bioequivalent drugs, in order to be considered therapeutically equivalent, must contain safe auxiliary substances with well-established properties, for example, ancillary substances may change the profile of its safety (and they may not affect the bioavailability of the active ingredient and, accordingly, bioequivalence). Any change in the composition of ancillary substances can significantly change not only its bioavailability, but also the quality of the drug, lead to toxic or allergic phenomena.

The study of the processes of absorption and biotransformation of drugs has shown that their intensity is particularly emphasized:

- the physical and chemical properties of medicinal substances (the presence of stereoisomers and polymorphic modifications, the degree of grinding of the medicinal substance, solubility);

- the nature of the auxiliary substances used;

- technological operations when receiving a drug;

- medicinal form.

Polymorphism. This term is used to determine the ability of a substance to exist in several crystalline forms with different physical and chemical properties, but having the same composition of chemical elements. Each of these forms (polymorphic modifications) is stable under certain external conditions (temperature, pressure, humidity, $\mathrm{pH}$ of the environment, etc.). Currently, polymorphic modifications have been detected in more than $70 \%$ of drugs from different pharmacological groups of drugs. Their formation usually occurs when solvents are replaced, drying parameters change, pressure pressure, $\mathrm{pH}$ changes in liquid environments. Polymorphic changes in drugs often cause changes in solubility, rapid inactivation of drugs, changes in their bioavailability and toxicological 
characteristics. The manufacture of drugs without taking into account polymorphic modifications of the substance is one of the reasons for the therapeutic nonequivalentity of drugs from different manufacturers. Given the importance of this fact, in a number of countries the national pharmacopeia (including European, Japanese) contain common pharmacopeia articles on polymorphism.

The degree of grinding. As the particle size decreases, the surface energy of the crushed substances increases dramatically. At the optimal fine degree of grinding substances are better dissolved.

The speed and fullness of suction, its concentration and the time of stay in the body vary greatly depending on the size of particles, for example:

- When the size of acetylsalicylic acid particles decreases by 30 times, compared to the usual used in pharmacy practice, the therapeutic activity of the drug increases by 2 times.

- Micronization of griseophulfin particles to less than 5 microns increases its efficiency by more than 2 times. A similar phenomenon is observed in micronification and other drugs such as sulfonylamides, levomycetin, tetracycline and others.

Drug soluble. Usually more soluble substances are released faster from medicinal forms, more easily diffuse to the place of absorption, faster show therapeutic action. At the same time, hard-to-use medicinal substances are more suitable for prolonged action. This characteristic may vary, for example, the solubility in water of the substance ibuprofen depends on the conditions of crystallization.

\section{The role of ancillary substances in the composition of drugs.}

Modern medicines use about 200 substances that make up the auxiliary group, and there is a tendency to increase it constantly.

The term "assistant substances" includes a huge group of natural and synthetic materials, the use of which in pharmaceutical practice is based on two prerequisites:

1 - indifference to macroorganism and active ingredients, 
2 - formative ability. The formative ability of ancillary substances was the main criterion in choosing the technological regimen of obtaining drugs and was determined by the degree of simplicity and commercial quality of the drug into medicine.

From a biopharmaceutical point of view, ancillary substances are integral components of drugs as complex physical and chemical systems, as they bear a certain and often very significant responsibility for the therapeutic effect of drugs. This responsibility is manifested not only in maintaining the stability of the existing ingredients of drugs, but also, mainly, in the change in the process of absorption of active substances, the nature of their distribution in the body and elimination, the end result of which is a change in the therapeutic activity of the drug.

This provision can be illustrated in the following examples:

- When using paraffin, cholesterol and other hydrophobic ancillary substances in tablets that include corticosteroids, the rate of absorption of hormones drops dramatically. The latter are largely concentrated in the epithelial mucous, sensibilizing them. In this regard, there is an accumulation of drugs and increases the possibility of damage to the intestines with steroids.

- Lactose, as an auxiliary substance, accelerates the absorption of testosterone, slows the absorption of phenacetin, some sulfanilamides, phenobarbital. As a result, there has been a significant decline in therapeutic action.

- The therapeutic activity of sodium salicylate and paraaminosalicylic acid is reduced when they are jointly prescribed with such auxiliary substances as starch, ethylcellulose.

- The effectiveness of tetracycline is reduced in the presence of calcium and magnesium salts, as well as calcium, magnesium and talc stearates, which are often used as sliding substances in tablets.

- The introduction of powdered sugar has a positive effect on the rate of dissolution of the substance metronidazole, the addition of lactose increases the completeness of the release of ascorbic acid from the granular form. 
- The introduction of pectin reduces acute toxicity (including hepatotoxicity) of isoniazid. All this requires careful study of the issues arising in the selection of ancillary substances in pharmaceutical technology and only such auxiliary substances, which optimally disclose all the pharmacological properties of the drug, can be applied in combination with it - such is the immutable rule of biopharmaceutical search in this aspect.

In addition to the auxiliary substances, bioavailability and therapeutic efficacy of drugs determine the processes of obtaining medicines. Research in this regard focuses on comparative study of processes and production factors in order to select the best (in terms of therapeutic efficacy), for example:

- The amount of pressure and speed in the pressing of tablets causes a change in the time of the disintegration of tablets, affects the rate of dissolution of the active substances (and therefore their absorption).

- Granulation (especially wet) can cause a slowdown in the absorption of drugs.

- The composition and way of coating the tablets determine the place of their dissolution in the gastrointestinal tract and the rate of release from the drug form.

"In the production of injectable solutions, mixing conditions, materials from which the containers are made, the sterilization regime are important.

- Conditions of granulation can significantly change the stability of the drug: for example, granules of the anti-influenza anti-influenza drug, obtained in the blade mixer, loses quality 6 times faster, compared to samples prepared by granulation in a pseudo-burnt layer. The decay and biological activity of salamid tablets depends on drying conditions: in this case, the lyophile drying of granules is preferable.

- Receiving dibasol tablets by direct pressing the substance of dibazo in a mixture with ancillary substances: lactose, microcrystal cellulose, aerosyl, starch and calcium stearat allows you to get tablets with faster and fuller release of dibazole.

The role of the drug form. In connection with the development of analytical methods of drug control, and especially with advances in the identification of drugs in bodily fluids, data have been obtained indicating the dependence of the absorption rate of drug substances, their concentration in biological fluids, the nature of 
distribution in tissues and organs, as well as biotransformation from the type of drug form. This effect of the form is so significant that biopharmaceuticals supports the need to define it on a case-by-case basis. In today's conditions, high demands are placed on medicines and their medicines as carriers of medicines. First of all, the drug form should meet the objectives of the medical process, ensure the delivery of medicines to a given organ or tissues, the necessary degree and speed of release of the drug, as well as, if necessary, the long-term action of the drug. From a productary perspective, the drug form should have a high stability, both in physics and chemical, and microbiological. In addition, in today's conditions, medicines should be highly technologically advanced, as well as have affordable prices for the consumer, have sufficient comfort and economy in use.

Different technological approaches are used in the creation of medicinal forms with modified pellet-based releases: direct pelletization (for homogeneous) or layering on the nucleus (for heterogeneous) pellets. At the same time, depending on the hydrophilic-lipophilic properties of the medicinal substance, different types of equipment, types and amounts of ancillary ingredients are used. As a result, drugs with accelerated, controlled or prolonged release can be obtained.

The role of the drug form. In connection with the development of analytical methods of drug control, and especially with advances in the detection of medicines in bodily fluids, data have been obtained indicating the dependence of the rate of absorption of narcotic substances, their concentration in biological fluids, the nature of distribution in tissues and organs, as well as biotransformation from the type of drug form. This effect of the form is so significant that biopharmaceuticals supports the need to define it on a case-by-case basis. In today's environment, high requirements are imposed on medicines and their medicines as a carrier of drugs. First of all, the form of the drug should meet the goals of the medical process, ensure the delivery of drugs to a given organ or tissue, the necessary degree and speed of release of the drug, as well as, if necessary, the long-term effect of the drug. From a grocery point of view, the form of the drug should have high stability, both in physics and chemical, and microbiological. In addition, in today's conditions, medicines 
should be high-tech, as well as have affordable prices for the consumer, have sufficient comfort and savings in use.

Modern liposuction-based drugs are actively introduced into medical practice, which have unique properties to deliver drugs to target cells and, in addition, to reparate cell membranes. A wide range of synthetic auxiliary substances and new technologies used to produce liposomes, allows to obtain drugs with different characteristics of prolongation: from a few hours to months. This is determined by the nature and quantity of the polymer, its molecular mass, the ratio of components, the way microparticles are produced.

The examples considered suggest that the quality of medicines and their bioavailability depend on a number of pharmaceutical factors, such as humidity, looseness, bulk, variance of powders and granules, as well as production conditions and the type of drug form. Optimizing the compositions, technology, hardware design of the process, as well as determining the rational drug form, can significantly affect the success of drug therapy.

In the process of developing the technology of drugs formed a certain algorithm of interconnected stages, allowing with a high degree of probability to get highperformance drugs.

In the first stages of development, it is planned to study the physical-chemical, structural-mechanical and technological properties of medicinal substances, as well as the influence of physical and chemical factors (temperature, $\mathrm{pH}$ of the dissolution environment, the shape and size of particles of crystalline or amorphous structure, solubility and others) on the preservation of their properties, ensuring the detected pharmacological activity of the substance. An important point of this study is the decision to choose possible medicinal forms and forming components.

The next stage is to design experimental compositions, determine the optimal composition and quantity of ancillary substances that allow to obtain technologically high-quality medicinal forms in terms of their compliance with pharmacopeic requirements. In addition, a study is conducted on the effect of technological factors on the quality of the drug. The criteria for evaluation at this stage are the 
technological characteristics of the drug form. The result of research at this stage may be several variants of compositions, including different in quality and quantity of auxiliary substances, and several variants of technology with different conditions of drying, pressing, filtering, mixing, etc. The resulting model compositions that meet pharmacopeic requirements, further need to be studied from the point of view of biopharmaceutical, confirming their pharmacological effectiveness in laboratory conditions by methods in vitro and in vivo. The criteria for evaluation at this stage are the rate of dissolution, the degree and speed of the manifestation of the pharmacological effect in the introduction of developed model compositions in comparison with the drug substance and comparison drugs. The compositions selected at this stage are further examined on the criteria for stability in the storage process, and the impact of different types of packaging and conditions on the preservation of the properties obtained during the development process is studied. The data obtained during the research are reflected in the draft regulations (pharmacopeia articles, laboratory regulations of production). This algorithm is only an integral part of the overall scheme of creating a new drug, but it is at this stage of development that the need to take into account the biopharmaceutical aspects is manifested.

Studies of pharmaceutical, pharmacotherapy and toxicological properties of developed drugs are completed by their state registration, which is a permit for use in medical practice. Developed compounds and technology of drugs, ensuring their therapeutic effectiveness and stability in the process of transportation and storage when they are introduced into industrial production, quite often undergo some changes. Therefore, at the stage of introduction into industrial production, it is especially important to understand the need to comply with all the technological parameters set in the development process. This applies both to the compositions and the ratio of ingredients, and to compliance with the terms of the technological plan.

The resulting model compositions that meet pharmacopeic requirements, further need to be studied from the point of view of biopharmaceutical, confirming their pharmacological effectiveness in laboratory conditions by methods in vitro and in 
vivo. The criteria for evaluation at this stage are the rate of dissolution, the degree and speed of the manifestation of the pharmacological effect in the introduction of developed model compositions in comparison with the drug substance and comparison drugs. The compositions selected at this stage are further examined on the criteria for stability in the storage process, and the impact of different types of packaging and conditions on the preservation of the properties obtained during the development process is studied. The data obtained during the research are reflected in the draft regulations (pharmacopeia articles, laboratory regulations of production). This algorithm is only an integral part of the overall scheme of creating a new drug, but it is at this stage of development that the need to take into account the biopharmaceutical aspects is manifested.

Section 2. Biopharmaceutical classification system - tool for the development of the drug form

BCS has now become an essential and indispensable tool for assessing the interchangeability of replicated medicines. It is used as regulatory documentation in guidelines to determine bioequivalence and study kinetic dissolution in all of the world's leading regulatory agencies. According to this classification, medicines are divided into 4 classes according to biopharmaceutical properties: permeability and properties of solubility (table 1).

Table 1

Biopharmaceutical classification system

\begin{tabular}{|c|c|c|}
\hline $\begin{array}{c}\text { Biopharmaceutical } \\
\text { characteristics }\end{array}$ & \multicolumn{2}{|c|}{ Drug soluble } \\
\hline Permeability & $\begin{array}{c}\text { 1 class } \\
\text { High - High } \\
\text { (e.g. propranolol) }\end{array}$ & $\begin{array}{c}\text { Low - High } \\
\text { (e.g. ketoprofen) }\end{array}$ \\
\cline { 2 - 3 } & $\begin{array}{c}3 \text { class } \\
\text { High - Low }\end{array}$ & Low - Low \\
& (e.g. lysinoprenil) & (e.g. ciprofloxacin) \\
\hline
\end{tabular}


This classification is associated with a drug dissolution and absorption model, which identifies the key parameters controlling drug absorption as a set of dimensionless numbers:

- Absorption Number (An): Defined as the ratio of the mean residence time to mea $\mathrm{n}$ absorption time. It denotes the dimensionless dose/solubility ratio for the particular drug formulation. The dose/solubility ratio indicates whether the capacity of the GI fluid is sufficient to dissolve the entire dose administered.

$$
\mathrm{A}_{\mathrm{n}}=\mathrm{P}_{\mathrm{eff}} \times \mathrm{t}_{\text {res }} / \mathrm{R}
$$

- Dissolution Number (Dn): Defined as the ratio of mean residence time to mean dissolution time.

$$
\mathrm{D}_{\mathrm{n}}=\mathrm{t}_{\text {res }} / \mathrm{t}_{\text {Diss }}
$$

- Dose Number (D0): Defined as the mass divided by the product of uptake volume $(250 \mathrm{~mL})$ and solubility of drug.

$$
\mathrm{D}_{0}=\mathrm{M}_{0} / \mathrm{C}_{\mathrm{s}} \mathrm{V}_{0}
$$

where $\mathrm{M}_{0}$ is the dose of drug administered, $\mathrm{V}_{0}$ is the initial gastric volume $(\approx 250$ $\mathrm{mL}), \mathrm{C}_{\mathrm{s}}$ is the saturation solubility, tres is the mean residence time $(\approx 180 \mathrm{~min})$, tdiss is the time required for a drug particle to dissolve, $\mathrm{P}_{\text {eff }}$ is the effective permeability, and $\mathrm{R}$ is the radius of the intestinal segment.

BCS has several objectives: identifying stages limiting the rate of absorption for biopharmaceutical compounds; and the definition of an API class in LF with immediate release for which bioequivalence can be evaluated in vitro. To determine the factors limiting the absorption of API in the body, three main parameters are highlighted: dissolution time, effective intestinal permeability and absorbable dose.

The concepts of "biopharmaceutical solubility" and "pharmacopeical solubility" are not unambiguous. Pharmacopeic solubility shows the number of grams of API that can dissolve into $100 \mathrm{ml}$ of solvent at $20^{\circ} \mathrm{C}$. It does not take into account the equilibrium solubility of API in the physiological range of $\mathrm{pH}$, so BCS is not taken into account. 
The characteristic of biopharmaceutical solubility is the ratio of the maximum dose of drug registered for medical use, $(\mathrm{D}, \mathrm{mg})$ to solubility $(\mathrm{S}, \mathrm{mg} / \mathrm{ml})$ at this $\mathrm{pH}$ value:

\section{$\mathrm{D} / \mathrm{S}=\mathrm{Dmax} / \mathrm{S}$}

Biopharmaceutical solubility is not a constant value for a particular API and depends on its maximum recorded dosage or the highest single dose. Definitions of the terms "dissolution" and "permeability" according to the WHO and FDA ND differ. By the term "high solubility" the FDA implies that the ratio between the maximum dose and the solubility of the substance should be less or equal to $250 \mathrm{ml}$ in the $\mathrm{pH}$ interval of $1-7.5$ at a temperature $37 \pm 1{ }^{\circ} \mathrm{C}$.

Unlike the FDA, WHO and EMA recommend a different $\mathrm{pH}$ interval (1.2-6.8) to determine solubility. The definition of solubility is carried out by shaking in a thermostatic flask for 24-72 hours at $\mathrm{pH}$ values selected in accordance with the ionization of the AFI [63-65].

AFI, which has a ratio of $\mathrm{D} / \mathrm{S}$ does not exceed $250 \mathrm{ml}$, refer to "well (highly) soluble" in the corresponding water solution, others - to "low soluble". Permeability, according to BCS, is high if the absorption rate of AFI through the small intestine wall is at least $85 \%$.

Substances 1 class BCS (with high solubility and high permeability, are quickly released from the drug form and absorbed). With the introduction of such drugs, the probability of reaching peak concentrations in biovilogies exceeding therapeutic and responsible for the presence of side effects is high. Therefore, the drug form, designed to ensure the therapeutic efficacy and safety of the drug, should demonstrate a smoothed, prolonged release profile. First of all, in the development of a drug form for these substances, it is advisable to use technologies that slow down the release.

Examples of such technologies are as follows.

Transfer of the substance from the amorphous state to the crystalline state.

Creating suspensions in the case of liquid medicinal forms. 
Receiving inclusions of compounds, for example, with cyclodextrins, which in the liquid environment will gradually dissociate into individual molecules, significantly slowing down the dissolution of an easily soluble substance.

For example, this technology uses drugs in the form of lyophilisates for the preparation of infusions: "Edex" (Schwarz Pharma AG, Germany), "Vasaprostan" (BAYER SCHERING PHARMA AG, Germany), "Bethend" (PFIZER PGM, France), "Cyprolis" (Amgen Europe B.V., Netherlands) and others. However, this technology has limitations, as the parameters of the guest molecule are limited by the size of the cyclodextrin cavity (the molecular weight of the pharmaceutical substance should be from 100 to 400$)$.

It is not advisable to use substances with a high dose. It should be taken into account that the dosage of the substance in the drug form will increase significantly due to the use of oligome carrier, for example, the molecular mass of cyclodextrin exceeds 1000 Yes. In the case of liquid medicinal forms, due to the low solubility of the cyclodextrin themselves, often the pharmaceutical substance cannot be introduced into the drug form at the desired concentration. Due to the non-toxicity of crystal cyclodextrins, which are not metabolized, patients with moderate or severe kidney dysfunction may experience cumulative media. Cyclodextrins and their derivatives are mainly crystalline solid products, and despite the formation of water-soluble complexes, it is possible that they are concentrated in renal tissue, accompanied by the formation of a crystal that causes necrotic cell damage. In this regard, in recent years at the disposal of technologists have appeared modified by hydroxyl all the time, alkylation and sulfoallkylation of cyclodextrins, which have better soluble than native. For example, the solubility of hydroxypropil-beta-cyclodextrin is $65 \%$ at 25 degrees Celsius. They are safe and recommended for oral, ophthalmological, parenteral and local use.

Receiving matrix medicinal forms: tablets, pellets, pellets, gels. The main factor in the successful development of a drug with a matrix structure is the correspondence of the type and quantity of the matrix-forming ingredient of solubility and absorption of the pharmaceutical substance. Within certain limits, the variation of the release 
profile is possible with the help of technological factors, such as ancillary substances, the way the polymer is introduced into the drug form, the pressure of pressing, the size of the polymer particles, the size of the drug form, etc [66-67].

Substances 2 class BCS. Despite the high permeability, characterized by low solubility, which is for them the main factor limiting absorption. As a result, Grade 2 substances may demonstrate insufficient bioavailability, and a variety of technologies have been developed to improve the therapeutic effectiveness of such substances.

- Micronization to produce micron and submicron particles is carried out with the help of freeze-dried drying, spray drying, technologies based on the use of supercritical fluids. The latter allow to get a product with a predetermined distribution of particles by size, a certain shape, crystallineity, morphology of the surface. The effects of micronification are clearly demonstrated by the medicinal forms of glybenclamide, one of the most popular, studied and reliable sugar-lowering medicines. Traditional medicinal forms of glybenclamide cause a slow and gradually increasing onset of sugar-lowering effect associated with low bioavailability, which in conventional tablets of $5 \mathrm{mg}$ is $29-69 \%$. The bioavailability of the micronized form is approaching 100\%. The well-known drug Maninil (Berlin Hemi AG) contains micro-insensible gliblenamide, the full release of the active substance occurs within 5 minutes after the dissolution of the tablet, and the therapeutic concentration in the blood is reached within 15-30 minutes. Due to the high bioavailability, the daily dose of Maninil can be reduced by $30-40 \%$ compared to conventional glybenclamide tablets.

- Amorphization of substance particles.

- Receiving socrystals (which in the nodes of the crystal lattice contain molecules of two or more substances). This direction of modification of pharmaceutical substances is currently actively developing abroad. Typically, these are molecules of pharmaceutical substance and ancillary substance/ancillary substances. The location of the molecules is strictly defined, they are in the stechiometric ratio, but soxristals are not considered solvvat and salt. The individual components of the socrystals at room temperature are solid. Socrystals are formed by 
hydrogen, vandervaals and z-connections (by overlapping the nuclear orbiters), but not at the expense of ion forces. As a result, the pharmacological effect of the substance in the socrystal does not change, but changes the solubility, the rate of dissolution, hygroscopicity, stability, density; socrystals are subject to polymorphism. The co-crystals are slowly crystallized from the solution when the solvent is evaporated, sublimation, joint melting and other technological methods.

- Receiving solid variances, which are two- or multi-component systems, including a drug substance and a carrier containing a highly dispernged solid phase of a medicinal substance or its solid solutions in the media matrix with the possible partial formation of variable composition complexes with the material of the carrier [68-69].

- Solubilization, as the easiest technologically simple way to increase the solubility of substances, which does not require special technological processing of the substance, based on the fact that the composition of the drug form is introduced by co-loving agents, forming water-soluble structures with drugs. Usually carried out with the help of PAV: twin-80, PEG, PEO, PVP, poloxamers, cream. With the help of colovillization, the solubility of the pharmaceutical substance can be increased by 20-50\%. For example, the addition of poloxamer 188 increased the release of ibuprofen from capsules in 60 minutes from $45 \%$ to about $100 \%$. In recent years, Soluplus has been successfully researched as a co-lover ${ }^{\circledR}$, which is a matrix polymer consisting of polyethylene glycol-6000, vinyl prolacactam and vinylacetate. This polymer is designed to co-lice poorly soluble pharmaceutical substances and is suitable for hot melt extrusion. However, it can be successfully used in normal processes to use its sympathizeal properties.

Substances 3 class BCS. These substances have high solubility and low permeability, which for them is a regulatory factor of bioavailability. In such drugs, it is advisable to include ancillary substances that can increase absorption, such as PAW. It is possible to increase the intake of the drug into the body by including it in the delivery systems of medicines that can penetrate biomembranes, for example, liposomes, micella and other structures. 
Receiving solid variances, which are two- or multi-component systems, including a drug substance and a carrier containing a highly dispernged solid phase of a medicinal substance or its solid solutions in the media matrix with the possible partial formation of variable composition complexes with the material of the carrier.

In order to increase absorption, mucoadgesic drug forms are being developed, the main concept of which is the thesis that the long exposure of the drug form to the mucous, which is considered as a barrier to absorption, contributes to the complete release of the drug. Bioadgesic ancillary substances are usually swollen hydrophilic polymers, which are said to interact with glycoproteins in a layer of mucus by penetrating the hanging ends of the polymer chain into a layer of mucus, electrostatic interactions, interactions of functional groups. Bioadgesic polymers include: sodium carboxymetyl cellulose, carbopol 934P, GPMC, copolimimers vinylpirrolidone and vinylacetate, polymetethacrilate, sodium alginate, gelatin, pectin, chitosan, etc. For substances with low permeability in some cases, it is preferable to use small medicinal forms, for example, instead of tablets - pellets or microcapsules, which have a large specific surface, and if they are made of flour-agesic materials, contact with the mucous they will be provided, and therefore, possibly increased absorption from such a medicinal form [71-72].

Substances 4 class BCS. These substances with low solubility and low permeability, on the one hand, present problems due to low bioavailability in oral administration, but on the other - extremely relevant for drug therapy because of high effectiveness. Of all the medicines on the market today, $30 \%$ are in the grade II BCS and $10 \%$ are grade IV. Among the new developments, the share of such Class IV substances is even greater - up to $20 \%$.

In order to increase the bioavailability of substances with low parameters of solubility and permeability, it is advisable to use any technologies aimed at increasing bioavailability and therapeutic efficiency. A good example is the drug Caletra Meltrex ${ }^{\circledR}$ containing protease inhibitors of the human immunodeficiency virus lopinavir and ritonavir, belonging to the 4th class of BCS. Bioavailability of the pill form, obtained by standard technology, was $10 \%$, the drug gave a whole bunch of 
side effects from the gastrointestinal tract and other systems of the body. In order to increase bioavailability, soft capsules have been developed, in which the active substance is in a hydrophobic solution, usually of low concentration. Soft capsules Of Caletra ${ }^{\circledR}$ must be taken 6 units of medicinal form a day and stored in the refrigerator. Attempt to increase the quantities of active substances in the solution was unsuccessful: during storage there was recrystalization. The most successful drug was Caletra Meltrex ${ }^{\circledR}$, which is a tablet extrudate, obtained by the extrusion of melt, which allowed to solve the problem of extremely low soluble and absorption of lopinavir and ritonavir, significantly increasing their bioavailability and reducing the frequency of side effects. As the main carrier of the pharmaceutical substance used polymer copopidon (sopolimer vinylpirrolidone and vinylacetate 3:2), in the medicinal form its content is $65-75 \%$. To reduce the temperature of glassing and increase the release of the drug is introduced PAW - sorbital monolaurate. It should be noted that the temperature of the glass composition is lower than that many polymers, and above room temperature, as a result of the substance remain active and the medicinal form is stable at room temperature. Bioavailability of the drug is $18 \%$ higher than the bioavailability of the capsule form, and the frequency of side effects decreased: $78 \%$ of patients lost diarrhea or other problems with the gastrointestinal tract, the appearance of nausea decreased from $27 \%$ to $5 \%$ [73-75].

\section{Conclusion}

Creating a generic drug seems to be quite a challenge from a technological point of view. This is due to differences in the production of substances that lead to changes in particle size and different ratios of crystalline and amorphous forms, differences in the composition and quantitative content of impurities, as well as differences in the ancillary substances and processes of production of ready-made medicinal forms, i.e. the influence of variable pharmaceutical factors. Pharmaceutical factors are not related to the physiological features of the human body, but can significantly change the effectiveness and safety of LS.

The key to the successful development of a drug, the justification for the optimal drug form capable of revealing the full pharmacological effect of the drug, is the 
scientific justification of the materials used and technologies corresponding to the solubility and absorption of the drug, in order to ensure the desired profile of its release, which is possible with the use of BCS, which is recently a tool for justifying the design and technology of medicines.

\subsection{Comorbidities as factors influencing choice of drug in arterial hypertension therapy}

У країнах Європи серцево-судинні захворювання (СС3) є однією 3 основних причин передчасної смерті і втрати скоригованих на інвалідність років життя: у жінок, віком до 75 років, вони складають $42 \%$ всіх випадків смерті, у чоловіків - 38\%. Це потребує постійного вивчення епідеміологічного стану даної патології та постійного удосконалення і стандартизації підходів фармакотерапії [76, 77].

Артеріальна гіпертензія (АГ) - один зі станів, що належать в усьому світі до так званих «хвороб століття», «Хвороб цивілізації». Майже 20-25\% всього дорослого населення має підвищений артеріальний тиск (АТ), тобто страждає тією чи іншою формою АГ, причому частіше нездужають найбільш працездатні люди віком 30-60 років [78].

Відмінною особливістю АГ $є$ висока частота коморбідності. Корморбідність - це співіснування у одного пацієнта двох або більше захворювань, синдромів або психічних розладів, пов'язаних між собою єдиним патогенетичним механізмом або збігаються часу. Виходячи з цього визначення, пацієнти 3 АГ мають одну або кілька супутніх патологій. Співіснування декількох захворювань у одного і того ж пацієнта в вітчизняних роботах нерідко описується як поєднані, супутні, асоційовані захворювання і стани. Найбільш часто зустрічаються хронічна обструктивна хвороба легень (ХОЗЛ), цереброваскулярна хвороба, цукровий діабет, гіпотиреоз. Коморбідність призводить до взаємного впливу на перебіг захворювань, характер і тяжкість 
ускладнень, нерідко ускладнює діагностику, визначає особливості вибору антигіпертензивних препаратів.

Наявність коморбідності у хворих на артеріальну гіпертензію визначає не тільки вибір антигіпертензивних препаратів, але i цільові значення артеріального тиску. До хворих 3 АГ i коморбідністю вимагається індивідуальний підхід, комплексна діагностика та лікування з урахуванням всіх наявних патологій [79, 80].

У Європейському регіоні ВООЗ з 2012 р. діють Основи європейської політики «Здоров’я-2020», які визнають право кожної людини на здоров’я, незалежно від етнічної належності, статі, віку, соціального положення та платоспроможності. Важливим аспектом у покращенні діагностичнолікувального процесу $є$ його стандартизація [81]. Медичні стандарти $\epsilon$ складовими єдиного технологічного процесу, що припускає використання найефективніших за результативністю та економічністю методів діагностики i лікування 3 урахуванням усіх існуючих методик та індивідуальних особливостей пацієнта, перебігу хвороби, а також матеріальних, кадрових та інших можливостей медичних закладів, досягнень науки і техніки.

На виконання наказу Міністерства охорони здоров’я України (MO3) від 19.09.2011 № 597 «Про затвердження Галузевої програми стандартизації медичної допомоги на період до 2020 року» затверджено Наказом МОЗ від 24.05.2012 р. № 384 Уніфікований клінічний протокол первинної, екстреної та вторинної (спеціалізованої) медичної допомоги «Артеріальна гіпертензія», розроблений на основі адаптованої клінічної настанови «Артеріальна гіпертензія» як джерела доказової інформації про найкращу медичну практику. Наказом МО3 України від 13.06.2016 р. № 564 затверджено Уніфікований клінічний протокол первинної, вторинної (спеціалізованої) та третинної (високоспеціалізованої) медичної допомоги «Профілактика серцево-судинних захворювань», розроблений з урахуванням сучасних вимог доказової медицини, розглядає медико-організаційні підходи щодо проведення профілактики СС3 в Україні з позиції забезпечення наступності етапів медичної допомоги. 
Світовий досвід, узагальнений ВООЗ, свідчить про те, що своєчасна діагностика, проведення заходів первинної та вторинної профілактики, своєчасне призначання адекватної медикаментозної терапії, залучення до участі в процесі лікування пацієнта та членів його родини затримує прогресування захворювання, знижує ризик виникнення ускладнень, сприяє поліпшенню якості життя та збереженню працездатності.

За рекомендаціями ВООЗ кожна держава повинна фінансувати галузь охорони здоров'я на рівні не менше 5\% від ВВП. Такі країни, як Америка, наприклад, фінансують 14\% від ВВП, Німеччина - 11\%. В Україні в 2017 р. фінансування склало всього 2,6\% від ВВП. В умовах дефіциту фінансування галузі особливого значення набувають маркетингові та фармакоекономічні дослідження ЛЗ для раціоналізації використання коштів держави та громадян [82].

За результатами проведеного дослідження виявили, що для лікування пацієнтів хворих на АГ згідно 3 Уніфікованим клінічним протоколом первинної, екстреної та вторинної (спеціалізованої) медичної допомоги «Артеріальна гіпертензія» (Наказ МО3 від 24.05.2012 р. № 384) рекомендовано 5 основних фармакологічних груп ЛЗ першої лінії і 5 груп другої лінії.

У зв'язку 3 особливою значимістю проблеми коморбідності АГ i бронхообструктивних захворювань як в медичному, так i в соціальноекономічному плані наукові спільноти розробили рекомендації з діагностики та лікування хворих з АГ і ХОЗЛ. 3 урахуванням вимог, препаратами першого ряду є блокатори РААС (блокатори рецепторів до ангіотензину II (БРА) або ІАПФ) або антагоністи кальцію.

Тому нами проведено більш детальний аналіз для препаратів першої лінії (інгібітори АПФ, антагоністи кальцію тривалої дії, антагоністи рецепторів ангіотензину II, а також діуретики, бета-адреноблокатори), які представлені, як вітчизняними, так іноземними виробниками. Згідно 3 Протоколом рекомендовано 45 ЛЗ за міжнародною непатентованою назвою (INN), 8 з яких не були зареєстровані станом на грудень 2019 р., 2 - були представлені лише в 
комбінованій формі з іншими ЛЗ. Для наступного етапу дослідження обрано монопрепарати 3 цих груп.

Рекомендовані Л3 представлені 278 торговими найменуваннями (ТН). Серед зареєстрованих антигіпертензивних Л3 72\% складають Л3 іноземного виробництва (рис. 1), з яких близько 18\% - індійського, 11\% - німецького, по $5 \%$ словенського та угорського виробництва та інших країн.

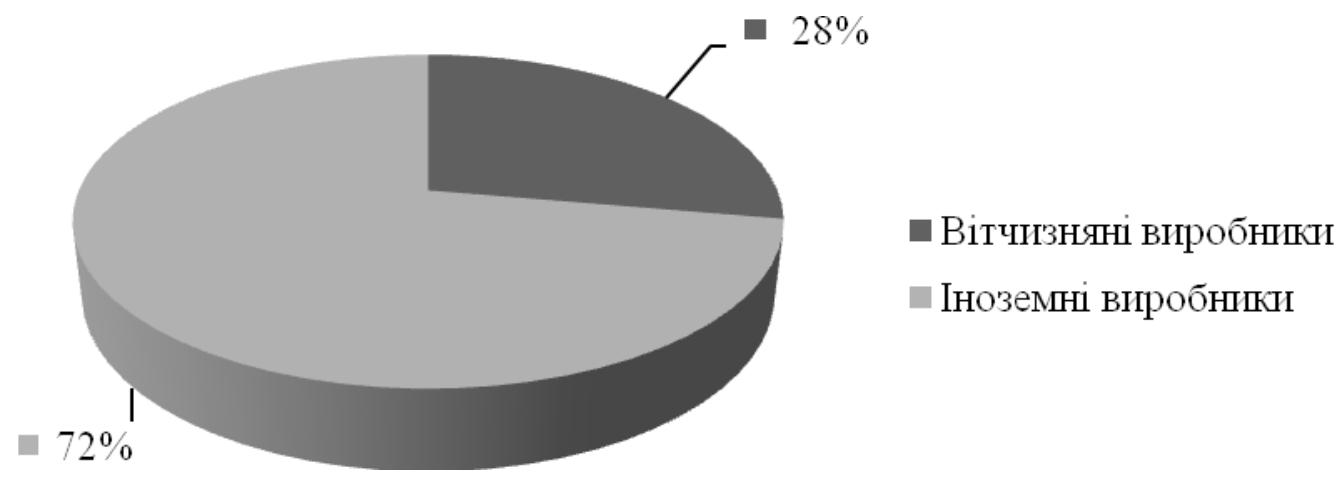

Рисунок 1. Співвідношення виробників антигіпертензивних ЛЗ

На наступному етапі проаналізовано окремо 5 досліджуваних груп ЛЗ. Діуретики зареєстровані 5 INN, 37 TH, 64 \% 3 яких виробляються іноземними виробниками (рис. 2).

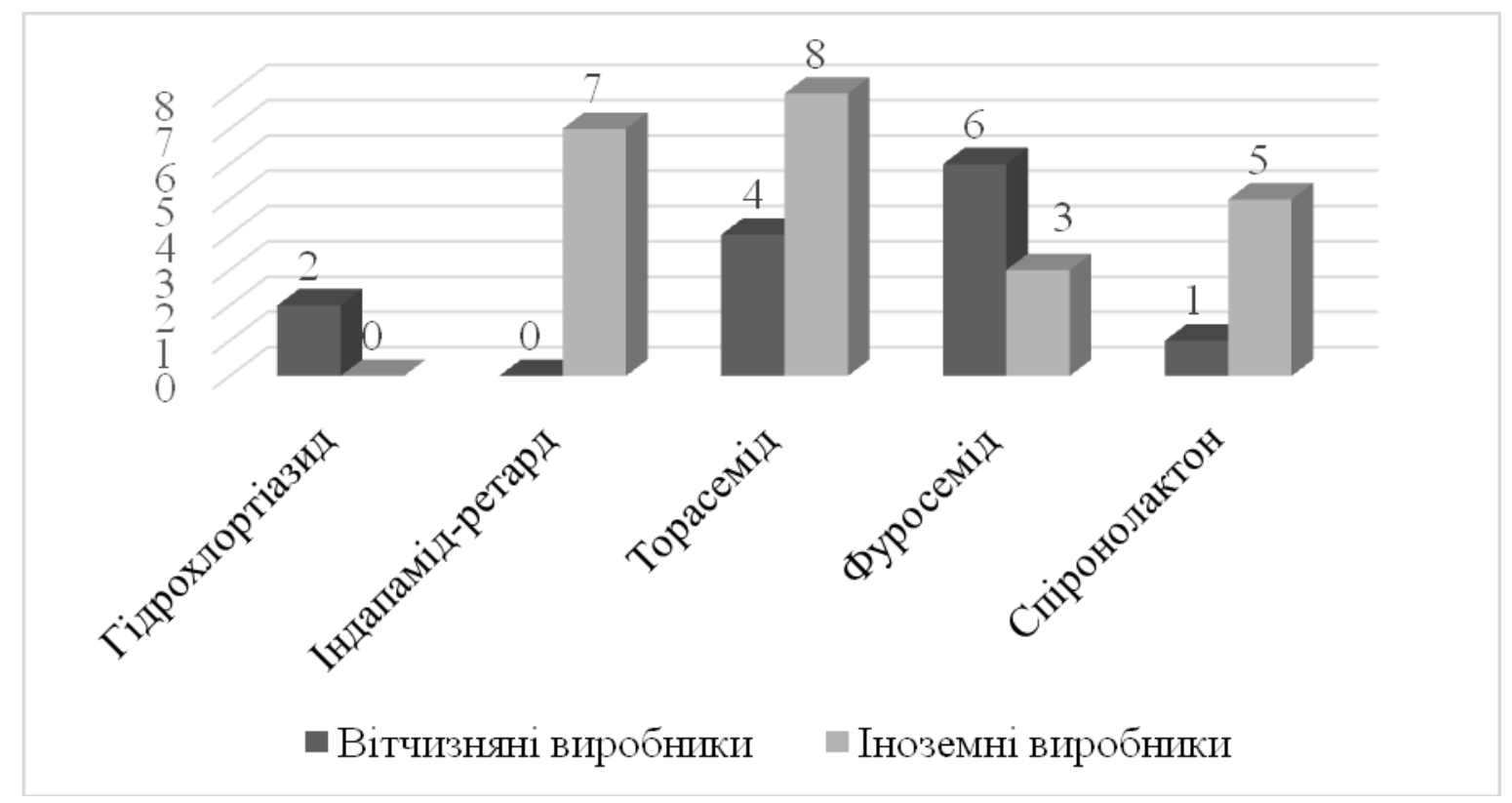

Рисунок 2. Співвідношення виробників діуретинів 
Серед групи антагоністів кальцію рекомендовано застосовувати 7 ЛЗ за INN, серед яких верапаміл і ділтіазем тривалої дії. Найбільш широко представлений асортимент амлодіпіну (рис. 3).

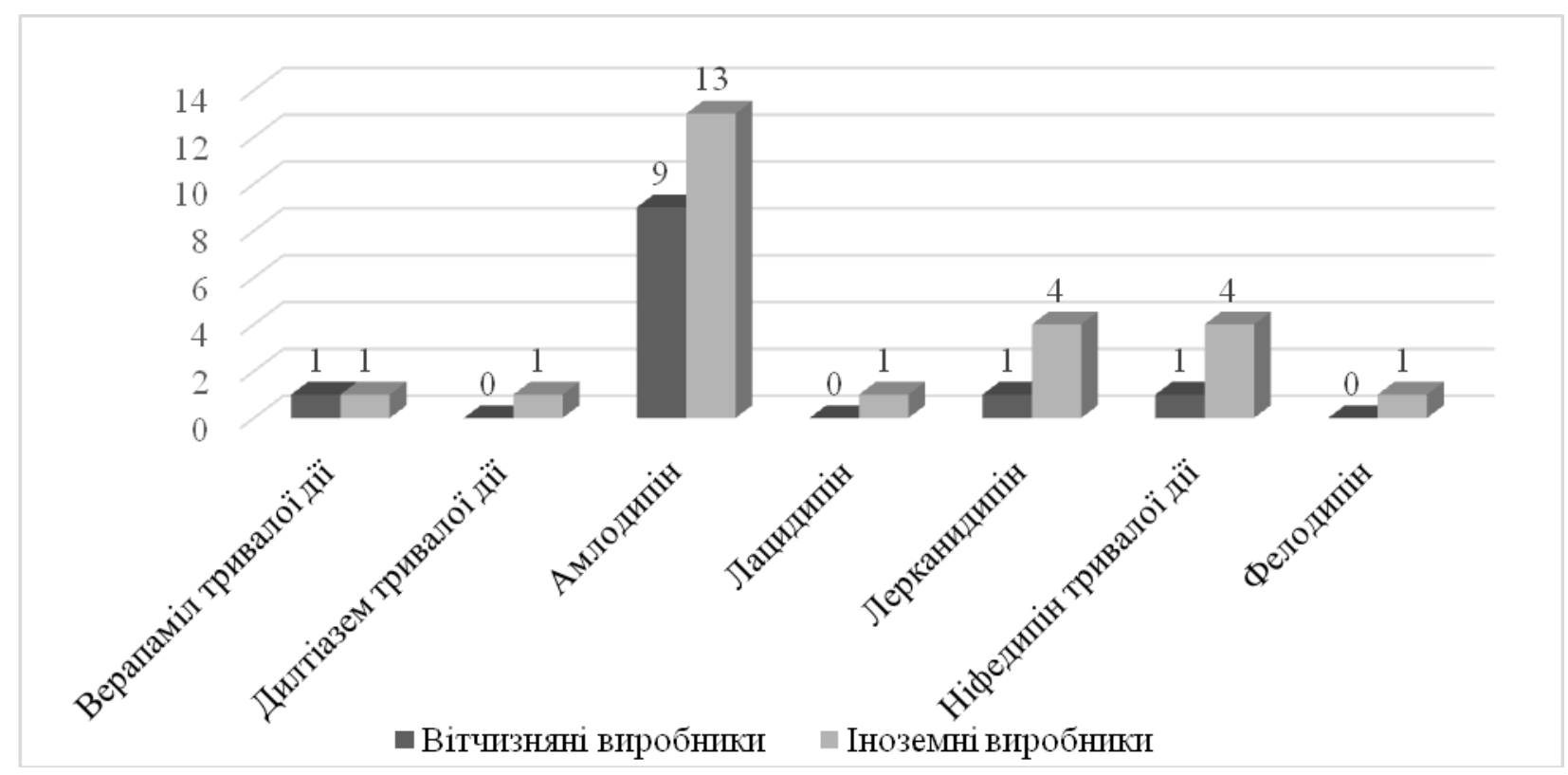

Рисунок 3. Співвідношення виробників антагоністів кальцію

Група інгібіторів АПФ характеризується найбільшим споживанням, $є$ самою широко представленою на українському ринку серед рекомендованих ЛЗ першої лінії. Серед ЛЗ іноземного виробництва найбільшим асортиментом характеризується лізиноприл та вітчизняного - еналаприл (рис. 4). 


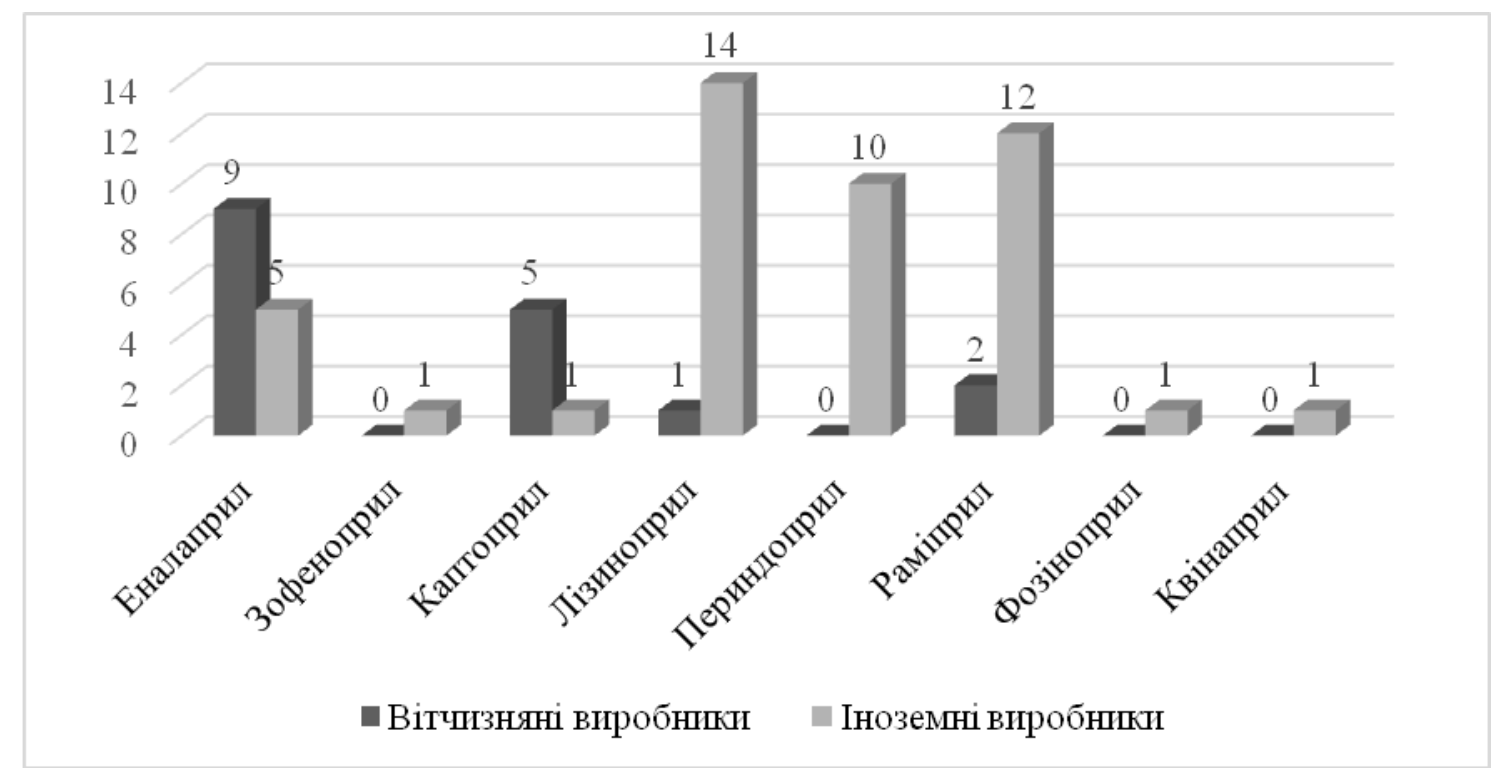

Рисунок 4. Співвідношення виробників інгібіторів АПФ

Серед блокаторів рецепторів ангіотензину II найбільший асортимент має валсартан (18 TH) та лозартан (12 TH), більшість з яких виробляється за кордоном (рис. 5).

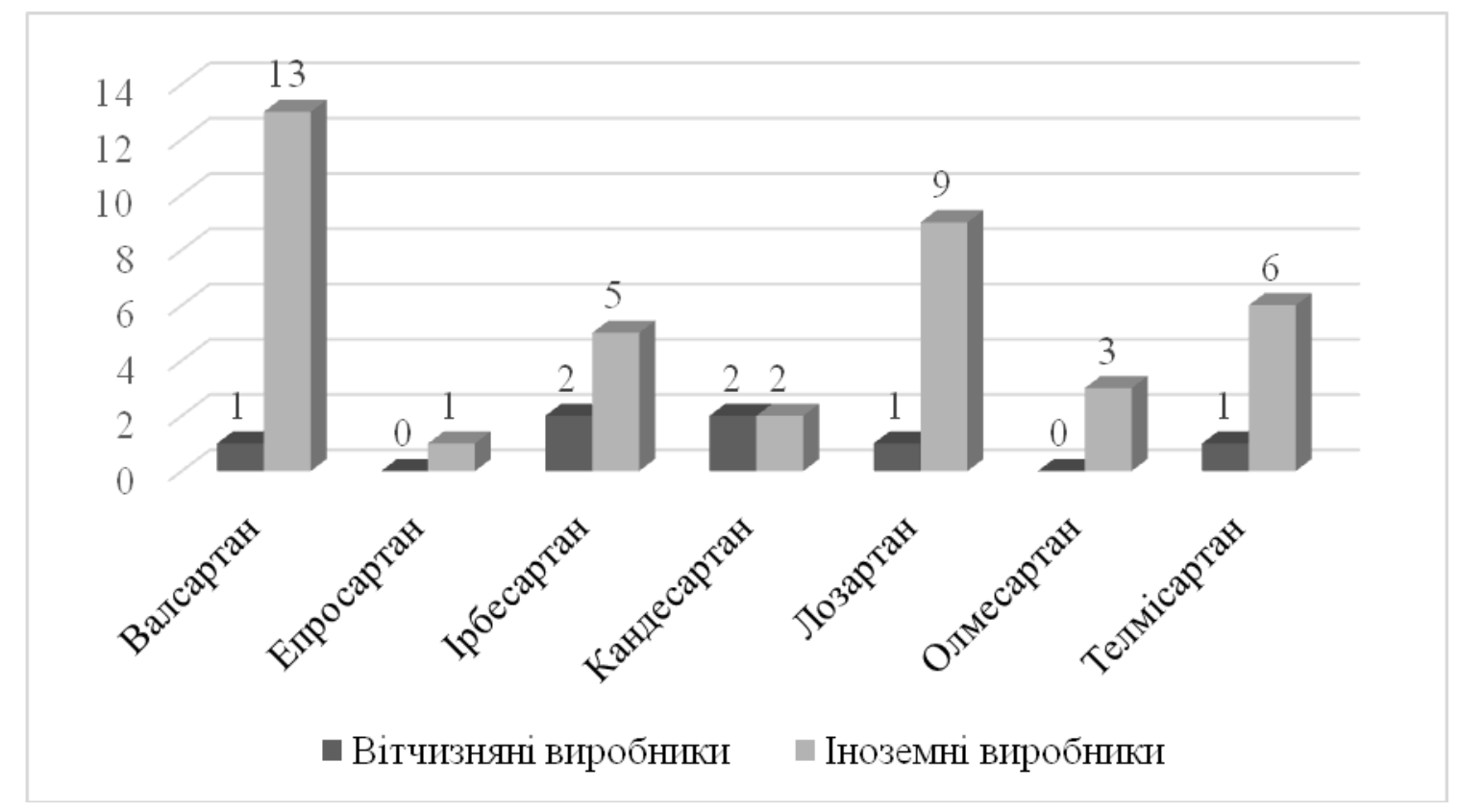

Рисунок 5. Співвідношення виробників блокаторів рецепторів ангіотензину II

В групі бета-блокаторів найбільший асортимент має бісопролол - $21 \mathrm{TH}$ Л3, які виробляються 6 вітчизняними та 11 іноземними заводами-виробниками (рис. 6). 


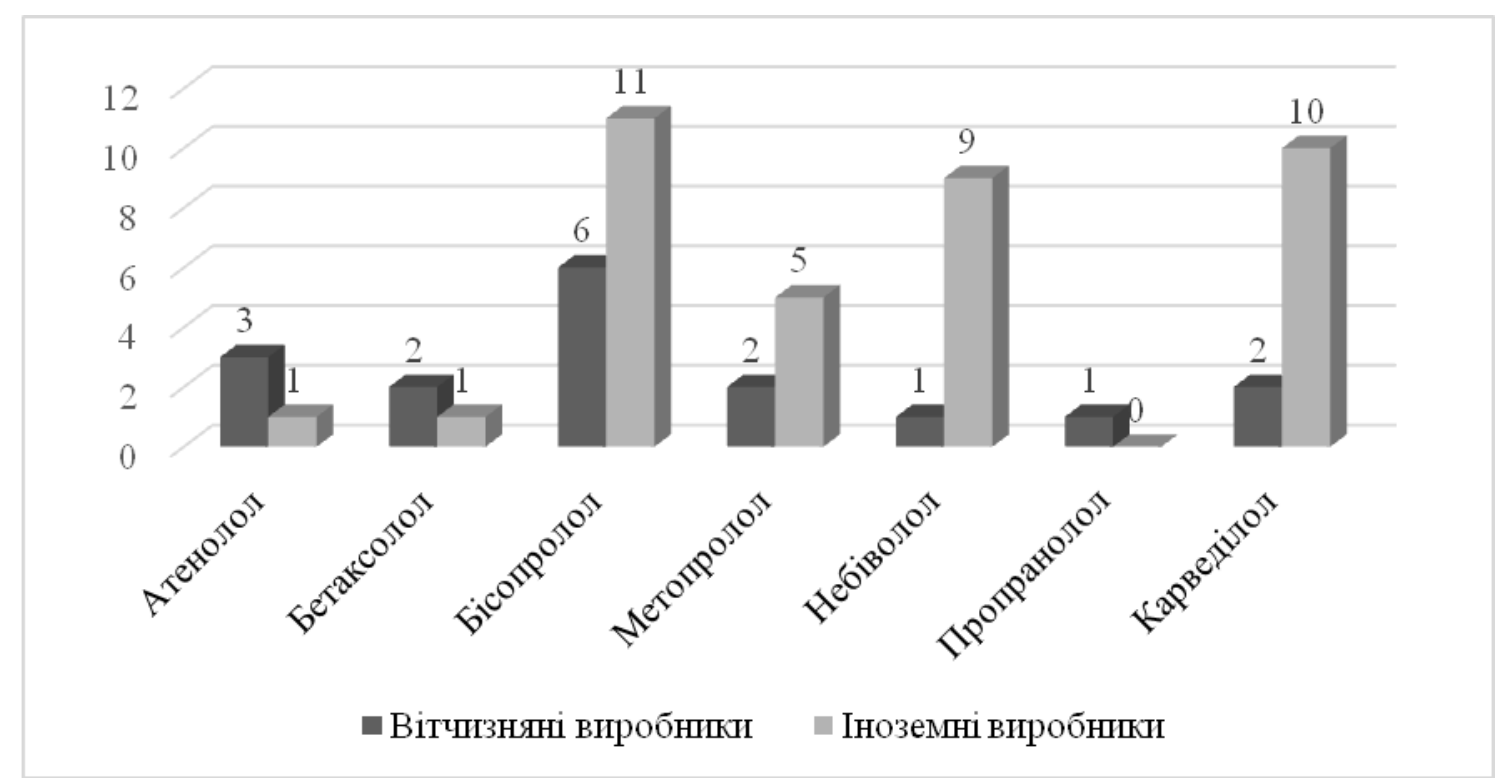

Рисунок 6. Співвідношення виробників бета-блокаторів

Для дослідження цінових характеристик була обрана група препаратів інгібітори АПФ, як найбільш численно представлена на ринку та група препаратів першого ряду для лікування хворих на АГ, що поєднана з ХОЗЛ.

Нами проаналізовані пропозиції провідних оптових фармацевтичних фірм України за оптовими цінами препаратів даної групи за 8 INN згідно 3 даними Щотижневика «Аптека» станом на грудень 2019 р. [ 83, 84].

Для кожного з препаратів був розрахований коефіцієнт ліквідності ціни $\left(K_{\text {liq }}\right)$, який відображає стан конкуренції на певному фармацевтичному ринку в конкретному періоді і частково може характеризувати доступність препаратів. Величина $K_{\text {liq }}(1)$ розраховувалася за формулою:

$$
\mathrm{K}_{\text {liq }}=\left(\mathrm{P}_{\mathrm{i} \text { max }}-\mathrm{P}_{\mathrm{i} \text { min }}\right) / \mathrm{P}_{\mathrm{i} \text { min }}
$$

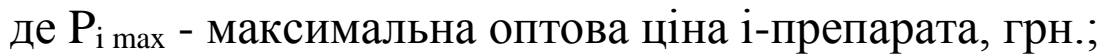

$\mathrm{P}_{\mathrm{i} \text { min }}$ - мінімальна оптова ціна i-препарата, грн.

Результати проведеного аналізу представлені в табл.1. Величина $K_{\text {liq }}$ більшості препаратів не перевищує 0,5, що підтверджує коректність і етичність операторів ринку по відношенню до споживачів. 
Коефіцієнти ліквідності лише двох препаратів, а саме: Еналаприл таблетки по 10 мг №20 (ПАТ «Київмедпрепарат», Україна) та Тритаце ${ }^{\circledR}$ таблетки по 5 мг № 28 (14×2) (Санофі С.П.А, Італія для ТОВ «Санофі-Авентіс Україна», Україна), перевищують значення 0,5 і відповідно рівні $\mathrm{K}_{\text {liq }}$ 0,55 та 0,59. Це вказує, що їх оптові ціни в пропозиціях різних фармацевтичних фірм відрізняються на 55\% і 59\% відповідно, що не є етичним підходом до ціноутворення.

Таблиця 1

Результати розрахунку коефіцієнтів ліквідності ціни інгібіторів АПФ

\begin{tabular}{|c|c|c|c|c|c|c|c|c|c|}
\hline \multirow{4}{*}{$\begin{array}{l}\text { № } \\
\text { 3/ } \\
\Pi\end{array}$} & \multirow{4}{*}{\multicolumn{2}{|c|}{ INN }} & \multicolumn{6}{|c|}{ Величина коефіцієнту ліквідності } & \multirow{4}{*}{$\begin{array}{l}0 \\
0 \\
0 \\
0\end{array}$} \\
\hline & & & \multirow{2}{*}{\multicolumn{2}{|c|}{$\begin{array}{l}\text { Kliq } \leq 0,15 \\
\text { Виробники }\end{array}$}} & \multirow{2}{*}{\multicolumn{2}{|c|}{$\frac{0,16 \leq K_{\text {liq }} \leq 0,50}{\text { Виробники }}$}} & \multirow{2}{*}{\multicolumn{2}{|c|}{$\frac{K_{\text {liq }} \geq 0,51}{\text { Виробники }}$}} & \\
\hline & & & & & & & & & \\
\hline & & & 1 & 2 & 1 & 2 & 1 & 2 & \\
\hline 1 & Еналаприл & Кількість & 5 & 8 & 9 & 1 & 1 & - & 24 \\
\hline & & $\%$ & 20,8 & 33,3 & 37,5 & 4,2 & 4,2 & - & 100 \\
\hline \multirow[t]{2}{*}{2} & Зофеноприл & Кількість & 5 & 5 & - & - & - & - & 10 \\
\hline & & $\%$ & 50,0 & 50,0 & - & - & - & - & 100 \\
\hline \multirow[t]{2}{*}{3} & Каптоприл & Кількість & 5 & 3 & 1 & - & - & - & 9 \\
\hline & & $\%$ & 55,5 & 33,3 & 11,2 & - & - & - & 100 \\
\hline \multirow[t]{2}{*}{4} & Квінаприл & Кількість & - & 3 & - & - & - & - & 3 \\
\hline & & $\%$ & - & 100,0 & - & - & - & - & 100 \\
\hline \multirow[t]{2}{*}{5} & Лізиноприл & Кількість & 5 & 17 & 2 & 2 & - & - & 26 \\
\hline & & $\%$ & 19,2 & 65,4 & 7,7 & 7,7 & - & - & 100 \\
\hline \multirow[t]{2}{*}{6} & Периндоприл & Кількість & - & 6 & - & - & - & 1 & 7 \\
\hline & & $\%$ & - & 85,7 & - & - & - & 14,3 & 100 \\
\hline \multirow[t]{2}{*}{7} & Раміприл & Кількість & 2 & 16 & 1 & - & 1 & - & 20 \\
\hline & & $\%$ & 10 & 80 & 5 & - & 5 & - & 100 \\
\hline \multirow[t]{2}{*}{8} & Фозиноприл & Кількість & - & 3 & - & - & - & - & 3 \\
\hline & & $\%$ & - & 100 & - & - & - & - & 100 \\
\hline
\end{tabular}

Примітка:

1- вітчизняні виробники;

2- іноземні виробники.

Таким чином, АГ залишається однією з найактуальніших проблем охорони здоров'я у зв'язку з високою поширеністю, соціально-економічною значимістю і високою коморбідністю. Для лікування АГ, поєднаною з ХОЗЛ рекомендовано 35 INN Л3 першої лінії, що представлені 278 ТН. 72\% зареєстрованих 
антигіпертензивних ЛЗ складають ЛЗ іноземного виробництва. Група інгібіторів АПФ $є$ найбільш представленою на українському ринку. Найбільшим асортиментом характеризується еналаприл вітчизняного виробництва та лізиноприл - іноземного. Величина $\mathrm{K}_{\text {liq }}$ більшості препаратів не перевищує 0,5, що підтверджує коректність і етичність операторів ринку по відношенню до споживачів. 


\section{REFERENSES}

1. Концепція інформатизації охорони здоров’я України. - [Електронний pecypc]. - URL: https://moz.gov.ua/uploads/2/12639-pro_20190604_1_dod.

2. Павлов, С. В., Аврунін, О. Г., Злепко, С. М., Бодянський, Є. В., Колісник, П. Ф., Лисенко, О. М., Чайковський, І. А., Філатов, В. О. (2019). Інтелектуальні технології в медичній діагностиці, лікуванні та реабілітації: монографія. С. В. Павлов, О. Г. Аврунін (ред). Вінниця: ПП «ТД «Едельвейс і К».

3. Поворознюк, А. І., Поворознюк, О. А., Мумладзе, Г. Р. (2017). Інформаційна підтримка діагностично-лікувальних заходів у медицині. Інформаційні технології та комп'ютерна інженерія, (1), 30-36.

4. Аврунін, О. Г., Бодянський, С. В., Калашник, М. В., Семенець, В. В., Філатов, В. О. (2018). Сучасні інтелектуальні технології функціональної медичної діагностики. Харків: ХНУРЕ.

5. Білобородова Т.О., Скарга-Бандурова I.С. (2018). Комплексний підхід до обробки різнорідних медичних даних 3 відсутніми значеннями. Вісник Національного технічного університету «ХПІ», (1318), 180-187.

6. Штофель Д. Х., Коваль Л. Г., Злепко С. М., Космач Л. В. (2013). Медична система прийняття та підтримки прийняття рішень. Вісник НТУ «ХПІ». Серія: Інформатика та моделювання, (992), 167-172.

7. School of Medicine: Stanford Medicine 2017 Health Trends Report Harnessing the Power of Data in Health, 2017. [Електронний ресурс]. - URL: https://med.stanford.edu/content/dam/sm/smnews/documents/StanfordMedicine/Heal thTrendsWhitePaper2017.pdf

8. Bulavenko O.V., Muntian O.A. (2018). Peculiarities of the diagnostics of miscarriage in early terms in women with recurrent miscarriage. Galician medical journal, (1), 177-189. 
9. Practice Committee of the American Society for Reproductive Medicine Evaluation and treatment of recurrent pregnancy loss: a committee opinion. // Fertil Steril. - 2012. - № 98(5). - P. 1103-1111.

10. Щорічна доповідь про стан здоров’я населення, санітарноепідемічну ситуацію та результати діяльності системи охорони здоров'я України. 2017 рік / МОЗ України, ДУ «УІСД МОЗ України». - Київ : МВЦ «Медінформ», 2018. - 458 с.

11. Аспекты репродуктивного здоровья населения Украины / Н. В. Авраменко, Д. Е. Барковский // Запорожский медицинский журнал. - 2010. - т. 12, № 3. - C. 71-73

12. Стан здоров'я жіночого населення в Україні за 2017 рік. [Електронний ресурс] / Центр медичної статистики МОЗ України - 2018. - Режим доступу до pecypcy: http://medstat.gov.ua/ukr/MMXVII.html / (дата звернення 20.04.2020). Назва з екрану.

13. Dysmenorrhea and endometriosis in the adolesctnt. - AGOG Committee Opinion № 760. American College of Obstetricians and Gynecologists. J. Obstet. Gynecol. - 2018. - № 132. - P. 249-258.

14. Стан здоров'я жіночого населення в Україні за 2018 рік. [Електронний pecypc] / Центр медичної статистики МОЗ України - 2019. - Режим доступу до pecypcy: http://medstat.gov.ua/ukr/MMXVII.html / (дата звернення 20.04.2020). Назва з екрану.

15. Рак в Україні: захворюваність, смертність, показники діяльності онкологічної служби [Електронний ресурс] / 3.П. Федоренко, Л.О. Гулак, Є.Л. Горох, А.Ю. Рижов, О.В. Сумкіна, Л.Б. Куценко. - 2019. - Режим доступу до pecypcy: http://www.ncru.inf.ua/publications/ (дата звернення 14.04.2020). - Назва з екрану.

16. Слабкий Г.О. Захворювання жінок України на інфекції, що передаються статевим шляхом як проблема первинної медичної допомоги / Г.О. Слабкий, I.С. Миронюк, О.С. Щербинська // Україна. Здоров'я нації. - 2019. № 3 (56). - С. 65 - 73 . 
17. Слабкий Г.О. Характеристика абортів у жінок України/Г.О. Слабкий, О.С.Щербинська // Економіка і право охорони здоров’я України. 2019. - №1C. $70-74$

18. Мировая статистика здравоохранения. 2017 год. - Режим доступа : https://whodc.mednet.ru/ru/osnovnye-publikaczii/epidemiologiya-istatistika/2671.html - Название с экрана.

19. Оковитый CB, Суханов ДС, Заплутанов BA, Смагина $\mathrm{AH}$. Антигипоксанты в современной клинической практике. Клиническая медицина. 2012;9:63-68.

20. Лукьянова ЛД. Современные проблемы адаптации к гипоксии. Сигнальные механизмы и их роль в системной регуляции. Патологическая физиол. и експеримент. терапия. 2011;1:2-18.

21. Медникова ЮС, Кожечкин СН, Копитова ФВ, Коштоянц ОХ. Приспособительная функция мозга и проблемы гипоксии. Патологическая физиол. и експеримент. терапия. 2012;3:33-41.

22. Самойлов MO, Рыбникова EA, Чурилова AB. Сигнальные молекулярные и гормональные механизмы формирования протективных эффектов гипоксического прекондиционирования. Патологическая физиол. и експеримент. терапия. 2012;3:3-10.

23. Obrenovitch TP. Molecular physiology of preconditiooning-induced brain tolerance to ischemia. Physiol. Rev. 2008;88:211-247.

24. Бублій ЮС. Гепарин: фізіологічна роль і клінічне значення порушень вмісту (огляд літератури). Укр. журн. гематол. та трансфузіол. 2013:1;5-10.

25. Spiller R. Serotonin and G1 clinical disorders. Neuropharmacology. 2008;55: 1072-1080.

26. Лычкова АЭ. Серотонинергическая регуляция моторной функции толстой кишки.Терапевтический арх. 2013;85;2:89-92.

27. Оковитый $\mathrm{CB}$, Смирнов $\mathrm{AB}$, Шуленин $\mathrm{CH}$. Клиническая фармакология антиоксидантов и антигипоксантов. СПб, 2005.128. 
28. 1. Gryshchenko, V.,Vovk, N., \& O. Shlapak (2017). Pro-antyokcydantna rivnovaga $v$ pechinci ta m'jazah cterljadi za dii' shtuchnogo gipobiozu $\mathrm{j}$ anestezii' [The pro- antioxidant balance in the liver and muscles of sterlet under carbon dioxide hibernation and anaesthesia]. Ukrainian journal of ecology, 7(3), 43-49. (in Ukrainian). doi: 10.15421/2017_47

29. 2. Hernandez-Munoz, R., Olguin-Martinez, M., Aguilar Delfin, I., SánchezSevilla, L., García-García, N., \& Díaz-Muñoz, M. (2013). Oxidant status and lipid composition of erythrocyte membranes in atients with type 2 diabetes, chronic liver damage, and a combination of both pathologies. Oxidative Medicine and Cellular Longevity. - 2013. - UNSP 657387. doi: 10.1155/2013/657387

30. 3. Tomchuk, V., Gryshchenko, V., Tsvilikhovskyi V., \& Illek J. (2019). Enterocytes membranes of the small intestine at pathology and conditions of hibernation. Czech Republic: University of Veterinary and Pharma-ceutical Sciences in Brno.

31. 4. BaraboyV. A. (2006). Bioantioksidanty [Bioantioxidants]. Kiev: Book plus. (in Russian).

32. 5. Gryshchenko, V. A., Tomchuk, V.A., \& Lytvynenko, O. M. (2010). Pokaznyky pro- ta antyoksydantnoi rivnovahy $\mathrm{v}$ orhanizmi shchuriv pry dii ionizuiuchoho vyprominiuvannia ta liposom. Naukovyi visnyk Natsionalnoho universytetu boresursiv i pryrodokorystuvannia Ukrainy, 151(1), 67-71. (in Ukrainian).

33. 6. Melnychuk, D. O., \& Gryshchenko, V. A. (2015). Rol' kyslotno-luzhnogo stanu ta fosfolipidiv moloka $\mathrm{u}$ formuvanni kolostral'nogo imunitetu $\mathrm{v}$ novonarodzhenyh teljat. [The role of acid-base status and the milk phospholipids in formation of colostral immunity of newborn calves]: edited by D. O. Melnychuk, Kiev: «CP Komprint». (in Ukrainian).

34. 7. Eileen, S. H., Khursheed, R. M., David, C. T., \& Daniel, L. G. (2013). Evaluation of antioxidant capacity and inflammatory cytokine gene expression in horses fed silibinin complexed with phospholipid. American J. of Veterinary Research, 74(10), 1333-1339. doi: 10.2460/ajvr.74.10.1333 
35. 8. Erisir, M., Kandemir, F. M., \& Yuksel, M. (2013). The effects of Caesarean section on lipid peroxidation and some antioxidants in the blood of newborn calves. Veterinarski Arhiv, 83(2), 153-159. URI: https://hrcak.srce.hr/99792

36. 9. Tomchuk V., Gryshchenko V., Vlizlo, V., \& Enciu V. (2019). Corrective effect of milk phospholipids in pathological conditions. Iaşi Editura Ion Ionescu de la Brad.

37. 10. Gryshchenko, V. A. (2019). Zhovchno-kyslotnyj sklad krovi ta zhovchi $\mathrm{v}$ teljat za enteropatologii' ta zastosuvannja fosfolipidiv moloka [Blood and acid composition of blood and biles in calves at enteropatology and application of milk phospholipids]. Ukrainian Journal of Veterinary Sciences, 10(4): 36-42. (in Ukrainian). doi: 10.31548/ujvs2019.04.005

38. 11. Melnychuk, D. O., Gryshchenko, V. A., Tereshchenko, S. V., \& Ribova Z. B.: Method for modeling gastroenteritis with ulcerative-erosive process in laboratory rats. Patent UA, 83904 (2008). (in Ukrainian).

39. 12. Melnychuk, D. O., Gryshchenko, V. A., \& Lytvynenko, O. N.: Veterinary biologically active additive of liposomal form and method of reparative therapy in hepatology. Patent UA, 86516 (2009). (in Ukrainian).

40. Батмангхелидж Ф. Ваше тело просит воды / Ф. Батмангхелидж; пер. с англ. - Минск: Попурри, 2013 . - 208 с.

41. Батмангхелидж Ф. Вы не больны, у вас жажда / Ф. Батмангхелидж; пер. с англ. - Минск: Попурри, 2008. - 320 с.

42. Behaviors and Attitudes Associated With Low Drinking Water Intake Among US Adults, Food Attitudes and Behaviors Survey, 2007 [Electronic resource] / A.B. Goodman, H.M. Blanck, B. Sherry [et al.] // Prev. Chronic Dis. - 2013. - Vol. 10. - Mode of access: http://www.cdc.gov/pcd/issues/2013/12_0248.htm

43. Beyond salt: lifestyle modifications and blood pressure / T.M. Frisoli, R.E. Schmieder, T. Grodzicki [et al.] // Eur. Heart J. - 2011. - Vol.32. - P. 3081-3087.

44. Daily self-monitoring of body weight, step count, fruit/vegetable intake, and water consumption: a feasible and effective long-term weight loss maintenance 
approach / J.D. Akers, R.A. Cornett, J.S. Savla [et al.] // J. Acad. Nutr. Diet. - 2012. Vol.112. - P. 685-692

45. Daniels M.C. Impact of water intake on energy intake and weight status: a systematic review / M.C. Daniels, B.M. Popkin // Nutr. Rev. - 2010. - Vol.68, №9. P. 505-521

46. Dr. Batmanghelidj in his own words [Electronic resource] - Mode of access: http://www.watercure.com/gallery.html

47. Drinking water consumption patterns of residents in a Canadian community / A.Q. Jones, C.E. Dewey, K. Dore [et al.] // J. Water Health. - 2006.- Vol.4, №1. P. $125-128$

48. Drinking water is associated with weight loss in overweight dieting women independent of diet and activity / J. Stookey, F. Constant, B. Popkin, C. Gardner // Obesity (Silver Spring). - 2008. - Vol.16, №11. - P. 2481-2488

49. Popkin B. Water, Hydration and Health / B. Popkin, K. D'Anci, I. Rosenberg // Nutr. Rev. - 2010. - Vol.68, №8. - P. 439-458

50. Popkin B.M. Water and food consumption patterns of US adults from 1999 to 2001 / B.M. Popkin, D.V. Barclay, S.J. Nielsen // Obes. Res. - 2005. - Vol.13, №12. - P. 2146-2152

51. Water consumption increases weight loss during a hypocaloric diet intervention in middle-aged and older adults / E.A. Dennis, A.L. Dengo, D.L. Comber [et al.] // Obesity (Silver Spring). - 2010. - Vol.18, №2. - P. 300-307

52. Zizza C.A. Total water intakes of community-living middle-old and oldestold adults / C.A. Zizza, K.J. Ellison, C.M. Wernette // J. Gerontol. A. Biol. Sci. Med. Sci. - 2009.- Vol.64, №4. - P. 481-486

53. 1. Isaenko, E.Yu. Adjuvants in modern vaccinology / E.Yu. Isaenko [et al.] // Annals of the Mechnikov Institute. - 2013. - No. 4. - S. 5-21.

54. 2. Kononov, A.V. Antigenic properties of the vaccine against coronavirus infection of cattle with different adjuvants / A.V. Kononov [et al.] // Proceedings of the Federal Center for Animal Health. - 2019.- T. 7. - S. 50-54. 
55. 3. Kryzhanovskaya, E.V. Adsorption and adjuvant properties of chitosan / E.V. Kryzhanovskaya [et al.] // Vetkorm. - 2008. - No. 4. - S. 34-35.

56. 4. Medunitsyn, N.V. Vaccinology / N.V. Medunitsyn // Ed. 2nd, rev. and add. - M .: Triad-X, 2014 .- 448 p.

57. 5. Mikhalishin, V.V. Adjuvants and their use / V.V. Mikhalishin, N.S. Mamkov // Tr. Federal Center for Animal Health. - Vladimir, 2008. - T. 6. - S. 340371.

58. 6. Nathalie Garçon. Vaccine adjuvants / Nathalie Garçon, Geert LerouxRoels, Wen-Fang Cheng // Perspectives in Vaccinology. - 2011 .-- Vol. 1, No. 1. - P. 89 - 113.

59. Wang, H., Li, Q., Reyes, S., Zhang, J., Xie, L., Melendez, V., Hickman, M. and Kozar, M.P. (2013). Formulation and particle size reduction improve bioavailability of poorly water-soluble compounds with antimalarial activity. Malaria Research and Treatment.

60. Dukhanin A.S., Shimanovsky N.L. Original and reproduced drugs: myths and reality // International Medical Journal. 2014. No1. S. 81-88.Wang R, Conner DP, Li BV. Bioavailability and bioequivalence aspects of oral modifi ed-release drug products. AAPS J. 2017;19(2):360-6.

61. Johnson, J.A. (2000). Predictability of the effects of race or ethnicity on pharmacokinetics of drugs. International Journal of Clinical Pharmacology and Therapeutics, 38, 53-60.

62. Ramenskaya G.V., Shokhin I.E., Kulinich Yu. I. Classifications of medicinal substances according to their biopharmaceutical properties - BCS and BDDCS. Bulletin of the Voronezh State University, series: chemistry. biology. Pharmacy, 2012, No. 1. S. 212-215.

63. The biowaiver procedure: modern approaches and general recommendations for assessing the in vitro equivalence of immediate release drugs / G. V. Ramenskaya [et al.]. Prescription. 2010. No. 5. C. 33-39.

64. Shilovskiy L., Kostin I. Introducing the polymorphism of diverticides into the pharmaceutical preparation of the licenses. Derzhavna registration drug-in- 
Ukraine in Ukraine. Pharmaceutical Chickens. 2011. No. 9. https://www.legalalliance.com.ua/publikacii/vpliv-polimorfizmu-diucih-recovin-nafarmacevticnu-rozrobku-likarskih-zasobivderzavna-reestracia-preparativ-dvijnikiv-vukraini/

65. Overview of the requirements for bioequivalence studies of generic drugs. FDA requirements. / A.N. Konyushkova, A. Yu. Savchenko, K. S. Davydov, and others. Remedium. 2011. No 5. P. 54-56.

66. Lindenberg M. Classifi cation of orally administrated drugs on the World Health Organization Model list of Essential Medicines according to the biopharmaceutics classifi cation system / M. Lindenberg, S. Kopp, J. Dressman. Eur. J. Pharm. Biopharm. 2004. Vol. 58. P. 265 - 278.

67. Shohin I. E. In vitro dissolution kinetics of amlodipine tablets marketed in Russia under biowaiver conditions / I. E. Shohin, G. V. Ramenskaya, G. F. Vasilenko, E. A. Malashenko. Diss. Tech. 2010. Vol. 3. P. 20-22.

68. Endrenyi L, Blume HH, Tothfalusi L. The two main goals of bioequivalence studies. AAPS J. 2017;19(4):885-90.

69. Jaber E. In vitro - In vivo Correlation: From Theory to Applications. J Pharm Pharmaceut Sci, 2006; 9: 169-189

70. Ulrich H, Florian S, Rolf D. Predicting in vivo absorption behavior of oral modified release dosage forms containing $\mathrm{pH}$-dependent poorly soluble drugs using a novel $\mathrm{pH}$-adjusted biphasic in vitro dissolution test. Eur. J. Pharm. Biopharm. 2010; 76 (1): 105-111

71. Mohd Y, Mohd A, Ashwani K. Biopharmaceutical Classification System: An Account. International J Pharm Tech Research. 2010; 2: 1681-1690

72. Saeed AQ. In Vitro-In Vivo Correlation (IVIVC) and Determining Drug Concentrations in Blood from Dissolution Testing - A Simple and Practical Approach. Open Drug Deliv J, 2010; 4, 38-47

73. Fatima R, Mahmood A, Ghulam M. Metoprolol Tartrate-Ethylcellulose Tabletted Microparticles: Development of a Validated Invitro In-vivo Correlation. IJMMS 2010; 1: 4211- 4214 
74. Brigas E.R., Uspenskaya E.V., Pisarev V.V. Study of the comparative kinetics of dissolution of a medicinal product of valsartan ii class of the biopharmaceutical classification system in accordance with the procedure “Biovaiver". Development and registration of medicines. 2016; (4): 152-157.

75. Brigas E.R., Uspenskaya E.V., Pisarev V.V. Dissolution profile studies of bcs class ii drug valsartan by biowaiver procedure. Drug development $\&$ registration. 2016;(4):152-157.

76. Вплив контролю артеріального тиску за допомогою блокатора кальцієвих каналів і різних інгібіторів ренін-ангіотензинової системи на показники центральної гемодинаміки й жорсткості артерій у пацієнтів 3 неускладненою артеріальною гіпертензією: результати шестимісячного спостереження / Амосова К. М., Лазарева К. П., Лазарев П. О., Руденко Ю. В. Серце і судини. 2016. № 1. С. 17-24.

77. Медик В.А. Заболеваемость населения: история, современное состояние и методология изучения. М.: Медицина, 2013. 512 с.

78. Мартишин О.О. Медико-соціальні проблеми артеріальної гіпертензії в Україні. Український медичний часопис. 2017.3 (119). С.1-3.

79. Давыдова И.В. Гипертоническая болезнь имеет разные лица. Ліки України. 2014. №7-8 (183-184). С 49-54

80. Шарабчиев Ю.Т., Антипов В.В., Антипова С.И. Коморбидность актуальная научная и научно-практическая проблема медицины XXI века. Медицинские новости. 2014. №8. С. 6-11.

81. Стандарти (протоколи) обстеження і лікування хворих - крок до підвищення якості діагностично-лікувального процесу / Веденко Б. Г. та ін. Новости медицины и фармации. 2010. № 10(326). URL: http://novosti.mifua.com/archive/issue-12687/article-12783/

82. Шелепко С. Скільки країни витрачають на охорону здоров'я? Щотижневик «Аптека». 2018. URL: http://www.apteka.ua/article/442558

83. «Еженедельник АПТЕКА»: веб-сайт. URL: http://www.morion.ua/ 
84. Фінансовий

портал

Минфин:

веб-сайт.

URL:

http://index.minfin.com.ua/index/average/. 